Biuletyn Historii Sztuki

LXXXII:2020, nr 4

ISSN 00063967

Bogusz WASIK

Malbork, Muzeum Zamkowe

https://orcid.org/0000-0002-2968-3015

\title{
Zamki w typie kasztelu jako siedziby dostojników kościelnych w Prusach
}

Castellum-type Castles as Residences of Church Dignitaries in Prussia 
W artykule omówione zostały kasztelowe zamki hierarchii kościelnej (biskupie i kapitulne) w Prusach. Jako adaptacja wzoru zamku konwentualnego cieszyły się długo mniejszym zainteresowaniem badaczy. Analiza obiektów w świetle nowych badań, pod kątem ich techniki budowy, układu przestrzennego i formy wykazuje wiele podobieństw jak i różnice w stosunku do zamków krzyżackich. Widać tu jednocześnie twórcze przetworzenie wzorca na własne cele funkcjonalne i propagandowe.

Słowa-klucze: zamki biskupie, zamki kapitulne, kasztel, zamek konwentualny, zakon krzyżacki

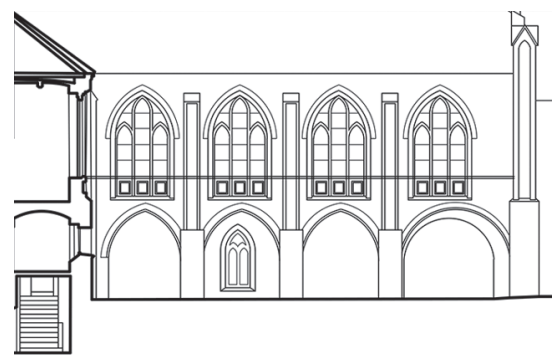

Castellum-type castles of the Church hierarchy (bishops and chapters) in Prussia are discussed. As an adaptation of the conventual castle model, for long they remained of lesser interest to scholars. The analysis of the facilities in the light of a new research, in view of their construction technology, spatial layout, and form, reveals many similarities as well as differences versus Teutonic castles. Additionally, a creative transformation of the model to serve the users' own functional and propaganda purposes can be observed

Keywords: episcopal castle, capitular castle, castellum-type castle, conventual castle, Teutonic Order 
$\mathrm{K}$

rajobraz architektoniczny Prus zdominowany jest przez wyjątkowo homogeniczną w skali europejskiej architekturę kasztelowych zamków konwentualnych. Buczy od a więc od przelomu lat $70-8$ Budziły one żywe zainteresowanie badaczy od samego początku kształtowania się dyscyplin naukowych zajmujących się architekturą i sztuką ${ }^{2}$. Uwagi takiej nie poświęcano jednak zamkom dygnitarzy kościelnych (biskupim i kapitulnym). Wynikało to nie tylko z faktu, że obiekty te (w tym interesujące nas kasztele) stanowiły mniejszość, ani też ze stanu ich zachowania. Mniejsze zainteresowanie wynikało bez watpienia $\mathrm{z}$ traktowania tych budowli jako, jak to ujął Karl Heinz Clasen, dzieł sztuki drugiej kategorii, będących wynikiem przejęcia formy. Miały być gorsze od pierwowzoru, stylistycznie opóźnione i przez modyfikacje pewnych elementów (jak artykulacji ścian blendami w Kwidzynie czy rezygnacji ze szczytów i pójściu w kierunku architektury bardziej rezydencjonalnej w Lidzbarku) cechować się zatraceniem doskonałych cech wyrazu zwartej formy zamków konwentualnych ${ }^{3}$. W ostatnich dziesięcioleciach sytuacja ta zmieniła się i zaczęto dostrzegać oryginalność w założeniach biskupich i kapitulnych ${ }^{4}$. Nie ulega przy tym oczywiście kwestii to, że kasztelowe zamki hierarchii kościelnej są powiązane z krzyżackimi i że mamy tu do czynienia z przejęciem wzorca oraz jego dostosowaniem do potrzeb właścicieli. Zwracano na to uwagę zarówno jeżeli chodzi o bryłę architektoniczną, jak i w warstwie układu

\footnotetext{
${ }^{1}$ Zob. m.in. Marian ArszyŃski, „Architektura warowna zakonu krzyżackiego w Prusach”, w: Fundacje artystyczne na terenie państwa krzyżackiego w Prusach, t. 2: Eseje, red. Barbara PosPieszna (Malbork: Muzeum Zamkowe, 2010), s. 745; Christofer Herrmann, „Kloster und Burg - die Architektur des Deutschen Ordens in Preußen und Livland”, w: Glaube, Macht und Pracht. Geistliche Gemeinschaften des Ostseeraums im Zeitalter der Backsteingotik, red. Oliver Auge, Felix Biermann, Christofer Herrmann (Rahden/Westf: Verlag Marie Leidorf, 2009), s. 209-219 (Archäologie und Geschichte im Ostseeraum, 6); Tomasz Torbus, Zamki konwentualne państwa krzyżackiego w Prusach (Gdańsk: słowo/ obraz terytoria, 2014); Bogusz WASIK, „Przekształcenia techniki budowy i architektury zamków krzyżackich w końcu XIII i początku XIV wieku w kontekście rozwoju państwa zakonnego w Prusach", w: Życie społeczno-kulturalne w państwie zakonu krzyżackiego (XIII-XVI w.), red. Jan GANCEwSKI et al. (Olsztyn: Instytut Historii i Stosunków Międzynarodowych Uniwersytetu Warmińsko-Mazurskiego, Fundacja Agencji Służb Społecznych, 2016), s. 115-136; ID., „Budownictwo i architektura zamków krzyżackich w Prusach”, w: Sapientia aedificavit sibi domum. Mądrość zbudowata sobie dom, red. Janusz Trupinda (Malbork: Muzeum Zamkowe, 2019), s. 364-383.

${ }^{2}$ Zob. Marian ArszyŃski, Budownictwo warowne zakonu krzyżackiego w Prusach (1230-1454) (Toruń: Wydawnictwo UMK, 1995), s. 51-74; ToRBus, Zamki konwentualne państwa krzyżackiego s. 13-28.

${ }^{3}$ Karl Heinz Clasen, Die mittelalterliche Kunst im Gebiete des Deutschordensstaates Preussen, t. 1: Die Burgbauten (Königsberg: Gräfe und Unzer Verlag, 1927), s. 158-172.

${ }^{4}$ M.in. Christofer Herrmann, „Mittelalterliche Bischofs- und Kapitelsburgen im Preußenland”, Burgenforschung aus Sachsen. Beiträge zur Burgenforschung im Freistaat Sachsen und angrenzender Gebiete, 15/16 (2003), s. 153-177; Liliana Krantz-DomasŁowska, „Der Dom und die Burg in Marienwerder (Kwidzyn)”, w: Burgen kirchlicher Bauherren, red. Thomas Biller (München-Berlin: Deutsche Kunstverlag, 2001), s. 215-222 (Forschungen zu Burgen und Schlössern, 6); Elżbieta PILECKA, „Residenz der ermländischen Bischöfe in Heilsberg (Lidzbark Warmiński) in der zweiten Hälfte des 14. Jahrhunderts", w: Prag und die grossen Kulturzentren Europas in der Zeit der Luxemburger (13101437), red. Markéta Jarošové, Jiří Kuthan, Stefan Scholz (Praha: Togga, 2008), s. 257-277.
} 


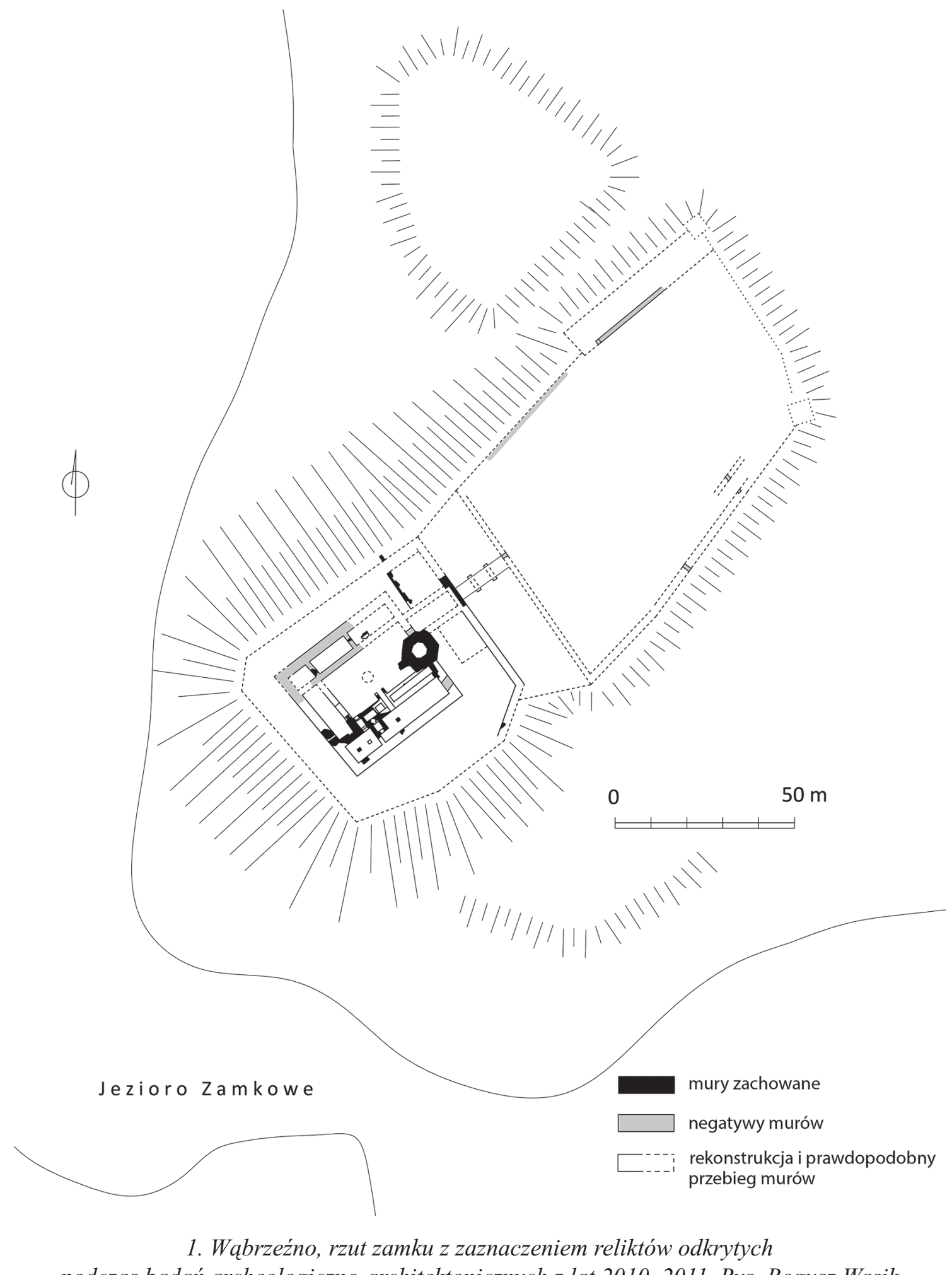

podczas badań archeologiczno-architektonicznych z lat 2010-2011. Rys. Bogusz Wasik

i funkcji wnętrz ${ }^{5}$. W ramach niniejszego artykułu zamierzamy przyjrzeć się, jak głęboko sięgają te podobieństwa i różnice, rozpatrując nie tylko formę architektoniczną i układ przestrzenny, ale także analizując technikę budowy kaszteli dostojników kościelnych

\footnotetext{
${ }^{5}$ Herrmann, „Mittelalterliche Bischofs- und Kapitelsburgen im Preußenland”, s. 153-158.
} 

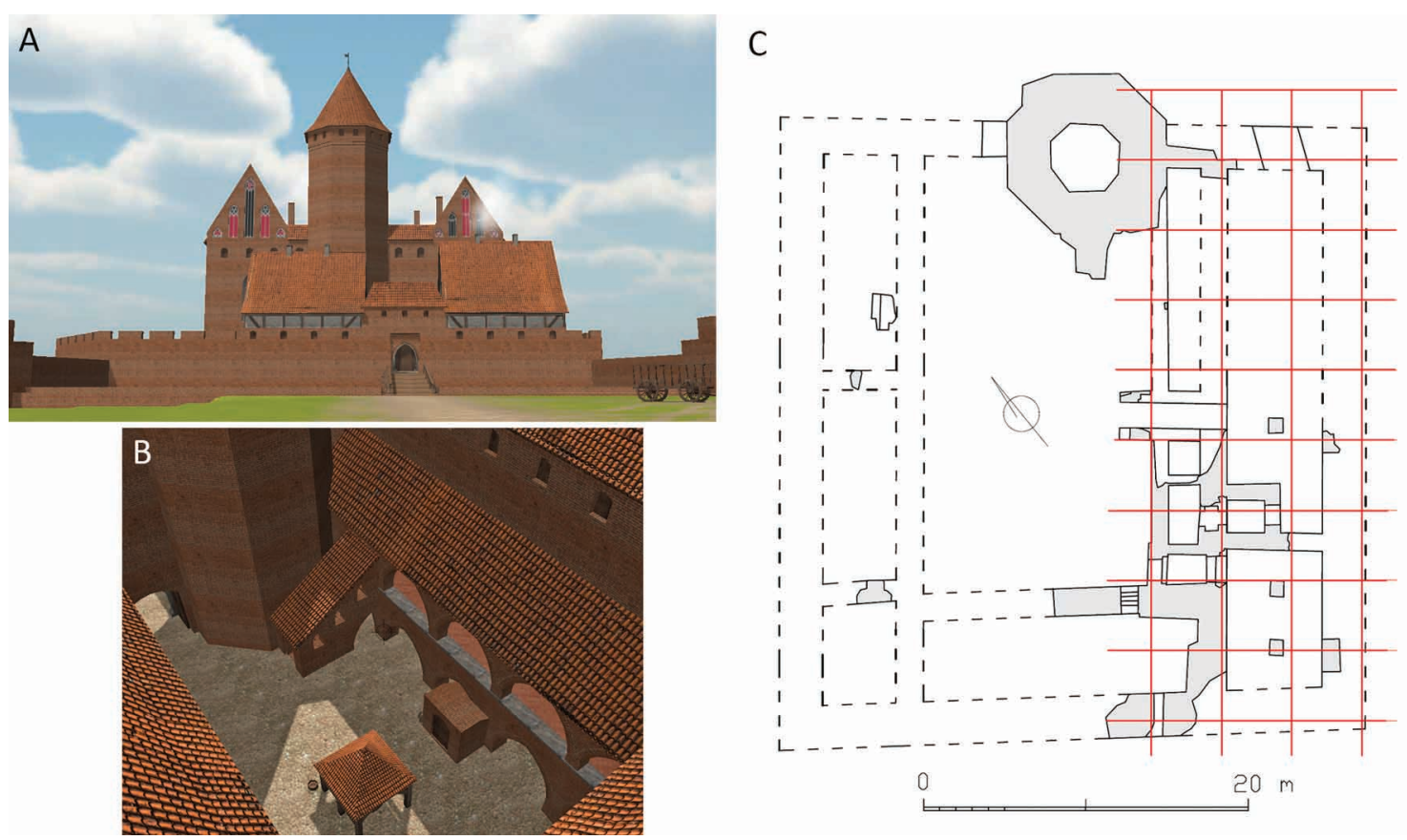

2. Wabrzeźno, zamek wysoki: A - widok od przedzamcza (stan z poczatku XVII w.); $B$ - rekonstrukcja dziedzińca z murowanymi schodami prowadzacymi na ganek skrzydla głównego. Koncepcja Bogusz Wasik, wizualizacja Pawet Moszczyński; C-rzut kasztelu z siatka o module 1 pręta nowej miary chetmińskiej na skrzydle głównym i ganku. Rys. Bogusz Wasik

i porównując warsztaty budowlane realizujące te zamki z wznoszącymi podobne budowle krzyżackie. Rozpoznanie tych wszystkich czynników (formy i układu przestrzennego oraz techniki budowy) da pełniejszy ogląd na wzajemne powiązania architektury zamków hierarchii kościelnej i zakonu krzyżackiego w Prusach.

Nową organizację kościelną na terenie państwa krzyżackiego w Prusach powołano w 1243 r., tworząc diecezje chełmińską, pomezańską, warmińską i sambijską. W ich ramach jedna trzecia obszaru przekazana została hierarchii kościelnej jako władztwa. W obrębie tych z kolei wydzielono dobra biskupie i kapitulne. Hierarchia kościelna, choć formalnie niezależna, dostała się wkrótce pod wpływ zakonu krzyżackiego i w ciaggu 2. połowy XIII w. większość kapituł przyjęła regułę zakonu, stając się jego członkami jako bracia duchowni. Z kapituł wybierani byli natomiast standardowo biskupi. Niezależną świecką kapitułą pozostała jedynie warmińska. Na terenie przyłączonego później do Prus Pomorza Gdańskiego pozostała stara organizacja kościelna biskupstwa włocławskiego $^{6}$. Biorąc pod uwagę fakt, że Krzyżacy zaczęli wznosić pierwsze zamki murowane w połowie XIII w. ${ }^{7}$, możemy stwierdzić, że budownictwo zamkowe hierarchii kościelnej było w stosunku do nich zapóźnione o ponad pół wieku. Rozpatrując jednak interesujące nas kasztele, różnica ta jest nieco mniejsza, gdyż, jak już zwracaliśmy uwagę, Krzyżacy przyjęli

\footnotetext{
${ }^{6}$ Marian Biskup, Gerard LaBuDA, Dzieje zakonu krzyżackiego w Prusach: gospodarka, społeczeństwo, państwo, ideologia (Gdańsk: Wydawnictwo Morskie, 1986), s. 169-171; Andrzej RAdzimí́ski, „Geneza oraz ukształtowanie się organizacji kościelnej (1206-1409)", w: Państwo zakonu krzyżackiego w Prusach. Władza i spoteczeństwo, red. Marian BIskup, Roman CZAJA (Warszawa: PWN, 2009), s. 145-156, 164-174.

${ }^{7}$ Szerzej na temat początków zamków krzyżackich zob. Bogusz WASIK, „Początki krzyżackich zamków na ziemi chełmińskiej. Pierwsze warownie i obiekty murowane”, Archaeologia Historica Polona 24 (2016), s. 233-260; ID., „The beginnings of castles in the Teutonic Knights' state in Prussia”, Castellologica Bohemica 18 (2018), s. 167-190.
} 
ten wzór później. Opóźnienie to wynikało bez wątpienia z mniejszych możliwości finansowych władztw kościelnych ${ }^{8}$.

Najwcześniejszym zamkiem interesującego nas typu była siedziba biskupów chełmińskich w Wąbrzeźnie. Wcześniejsze (Kwidzyn, Braniewo) reprezentowały inne typy formalne ${ }^{9}$. Dzięki cennej informacji w zredagowanym w początku XVI w. katalogu biskupów chełmińskich wiadomo, że budowę zamku w Wąbrzeźnie zaczął biskup Herman von Pri-

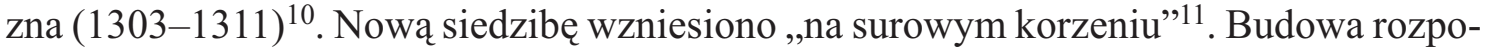
częta w pierwszej dekadzie XIV w. musiała toczyć się przez kolejne dziesięciolecia, zwłaszcza że po śmierci Hermana von Prizny nastąiła dekada wakatu na godności biskupa chełmińskiego. Zamek stał już w jakiejś formie w 1321 r., kiedy wystawił w nim dokument biskup Mikołaj. Dopiero jednak od połowy XIV w. biskupi zaczęli pojawiać się w Wąbrzeźnie częściej, z czego można wnosić, że w tym czasie ukończono budowę ${ }^{12}$.

Zamek wysoki poprzedzało od wschodu murowane przedzamcze na planie nieregularnym oraz zapewne drugie - drewniano-ziemne ${ }^{13}$ (il. 1). Główny człon zamku otoczony był murem zewnętrznym o wielobocznym narysie. Sam dom zamkowy był kasztelem na planie czworoboku o wymiarach $36 \times 37-38 \mathrm{~m}^{14}$. Nie miał jednak czterech, ale trzy skrzydła (il. 2: A-C), był więc formą zredukowaną. Nawiązywał bez wątpienia do wznoszonych w ostatniej ćwierci XIII i pierwszej XIV w. wczesnych krzyżackich kaszteli z ziemi chełmińskiej ${ }^{15}$, które, choć standardowo czteroskrzydłowe, też cechowały się m.in. pewną dowolnością i niekonsekwencją w stosowaniu pełnego programu elementów ${ }^{16}$. W Wąbrzeźnie główne

\footnotetext{
${ }^{8}$ Christofer Herrmann, Mittelalterliche Architektur im Preussenland. Untersuchungen zur Frage der Kunstlandschaft und-Geographie (Olsztyn: Artes; Petersberg: Michael Imhof Verlag, 2007), s. 252; ID., „Mittelalterliche Bischofs- und Kapitelsburgen im Preußenland", s. 156-157.

${ }^{9}$ Jako najstarszy wskazać należy tzw. stary zamek biskupów pomezańskich w Kwidzynie, wzniesiony w 2. połowie XIII w. na planie nieregularnym. Najprawdopodobniej nieco przed zamkiem w Wąbrzeźnie, bo około końca XIII lub przełomu XIII-XIV w., rozpoczęto też budowę zamku biskupów warmińskich w Braniewie, który był co prawda założeniem regularnym, ale z jedną kamienica; zob. Herrmann, Mittelalterliche Architektur im Preussenland, s. 375, 591; Waldemar HeYM, „Das «Altschlößchen» in Marienwerder”, Zeitschrift des historischen Vereins für Regierungsbezirk Marienwerder 69 (1933), s. 3-28; Zbigniew Nawrocki, „Zamek w Braniewie”, Rocznik Olsztyński 9 (1970), s. 81.

${ }^{10}$ Der Katalog der Bischöfe von Kulm, w: Scriptores rerum Prussicarum. Die Geschichtsquellen preussischen Vorzeit bis zum Untergange der Ordenscherrschaft, t. 6, oprac. Udo ARnold, red. Walter Hubatsch (Frankfurt am Main: S. Hirzel, 1968), s. 273.

${ }^{11}$ Wczesnośredniowieczne grodzisko zlokalizowane jest po drugiej stronie jeziora; zob. Wczesnośredniowieczne grodziska ziemi chetmińskiej. Katalog źródet, oprac. Ryszard Boguwolski et al., red. Jadwiga CHuDziakowA (Toruń: Uniwersytet Mikołaja Kopernika, 1994), s. 184-190.

12 Sławomir JóźwiAK, Janusz TruPINDA, „Zamek biskupów chełmińskich w Wąbrzeźnie na podstawie źródeł pisanych. Chronologia budowy i układ przestrzenny", w: Zamek biskupów chełmińskich w Wabrzeźnie w świetle badań archeologiczno-architektonicznych. Studia i materiały, red. Marcin Wiewióra (Toruń: Wydawnictwo Naukowe UMK, 2014), s. $50-51$.

${ }^{13}$ Bogusz WASIK, Budownictwo zamkowe na ziemi chetmińskiej (od XIII do XV wieku) (Toruń: Wydawnictwo Naukowe UMK, 2016), s. 308-310; ID., „Układ przestrzenny zamku w 1. połowie XVII wieku w świetle źródeł historycznych”, w: Zamek biskupów chełmińskich w Wąbrzeźnie, s. 57-59.

${ }^{14}$ Bogusz Wasik, „Próba rekonstrukcji etapów budowy i układu przestrzennego zamku na podstawie wyników badań historycznych, archeologicznych i architektonicznych”, w: Zamek biskupów chetmińskich w Wabrzeźnie, s. 207.

${ }^{15}$ Marcin WiEWIÓRA, Bogusz WAsIK, „Podsumowanie”, w: Zamek biskupów chelmińskich w Wąbrzénie, s. 221-222.

16 Tylko niektóre z nich otrzymały parchamy (Lipienek), w innych wykonano je tylko z wybranych stron (Kowalewo Pomorskie). Także wieżę główną (bergfrid) zrealizowano tylko w Lipienku. W Golubiu był planowany, ale go nie zbudowano, a w Papowie Biskupim wieży nie przewidziano. Także akcentowanie narożników wczesnych kaszteli chełmińskich miało różną postać - stosowano ryzalitowo wysunięte wieżyczki (Papowo Biskupie, Rogóźno), jak i nastawione na murach (Golub). W Lipienku prawdopodobnie w ogóle ich nie wykonano; zob. Torbus, Zamki konwentualne państwa krzyżackiego, s. 141-167; WAsIK, Budownictwo zamkowe na ziemi chetmińskiej, s. 271-292, 319-320.
} 
było skrzydło południowe, które jako jedyne miało podpiwniczenie i murowany ganek od strony dziedzińca. Na ten ostatni prowadziły reprezentacyjne murowane schody, umieszczone w południowo-wschodnim narożniku dziedzińca (il. 2: B). Brak dowodów, by stwierdzić, że przy pozostałych dwóch skrzydłach była kontynuacja ganku wykonana z drewna, tworząca dookolny krużganek. Nowożytne inwentarze na to nie wskazują. $\mathrm{Na}$ pierwszym piętrze skrzydła południowego, nad gospodarczymi kondygnacjami piwnic i parteru, mieściły się główne wnętrza zamku. Od wschodu była kaplica, w części środkowej refektarz, ogrzewany piecem typu akumulacyjnego (hypocaustum), a od zachodu komnata biskupa. Powyżej znajdowała się kolejna kondygnacja magazynowo-spichrzowa. W nowożytności pomieszczenia mieszkalne zajmowały także piętro skrzydła zachodniego i prawdopodobnie również w średniowieczu pomieszczenia te służyły biskupom $\mathrm{i}$ ich dworowi. $Z$ tej strony znajdował się też ustęp (gdanisko) o nieznanej bliżej formie. Nowożytne opisy milczą na temat funkcji wyższych kondygnacji skrzydła północnego być może, podobnie jak przyziemie, mieściły one pomieszczenia gospodarcze i magazynowe. Mniej więcej na osi kurtyny wschodniej umiejscowiona była flankująca bramę ośmioboczna wieża główna (il. 2: A). Taką jej lokalizację uznać należy za nietypową. Jeżeli chodzi o funkcje militarne, to umiejscowienie nie tylko umożliwiało kontrolę wjaz$\mathrm{du}$, ale także osłonę wnętrza zamku wysokiego od najłatwiej dostępnej strony. Nie była to jednak standardowa wieża w typie bergfridu, jakie budowano na zamkach krzyżackich, a więc dostępna przez most umieszczony kilka metrów nad ziemią. Jak wynika bowiem z opisów wejście do niej prowadziło bezpośrednio z ganku komunikacyjnego skrzydła głównego i znajdowało się w pobliżu schodów prowadzących na ten ganek z dziedzińca. Nie pełniła więc funkcji wieży ostatecznej obrony, a jej dominację w centrum zamku należy bez wątpienia rozpatrywać tym bardziej w kategoriach semantyki władzy ${ }^{17}$.

Przeprowadzone na zamku badania archeologiczno-architektoniczne dostarczyły także interesujących informacji odnośnie do techniki i warsztatu budowlanego. Widać tu pewne odstępstwa od standardów i rozmachu prac prowadzonych przy wznoszeniu kasztelowych zamków krzyżackich ${ }^{18}$. Co prawda wykopy fundamentowe ścian kasztelu wykonano starannie na zbliżonym poziomie, ale nie przeprowadzono charakterystycznych dla wznoszonych w tym czasie zamków krzyżackich wielkich prac ziemnych o charakterze nasypów, wyrównujących poziom dziedzińca i tarasu okalającego kasztel. W efekcie niezniwelowany dziedziniec był łagodnie pochyły. Ponieważ nie wykonano tarasów typowego parchamu - nasypy na międzymurzu stwierdzono jedynie od wschodu, a więc od strony wjazdu. Relikty zamku nie zachowały się w stopniu umożliwiającym przekonywającą analizę pod kątem zastosowania metod geometrycznych w projektowaniu, stwierdzić można jednak, że wytyczając skrzydło główne z krużgankiem zastosowano nową miarę chełmińską $^{19}$ (skrzydło i krużganek miały łącznie trzy pręty szerokości; il. 2: C). W etapowaniu realizacji widać kolejne odstępstwo od „krzyżackich standardów”, w których w pierwszej kolejności realizowano kurtynę obwodową kasztelu, a w dalszej sukcesywnie dostawiano skrzydła, poczynając od głównego. W Wąbrzeźnie stan zachowania nie pozwala na pełne rozpoznanie etapów budowy, ale wieża najprawdopodobniej powstała

\footnotetext{
${ }^{17}$ JÓŹWIAK, TRUPINDA, „Zamek biskupów chełmińskich w Wąbrzeźnie”, s. 53-55; WAsIK, Budownictwo zamkowe na ziemi chetmińskiej, s. 308; ID., „Układ przestrzenny zamku w 1. połowie XVII wieku”, s. 59-62; WIEWIóRA, WasIK, „Podsumowanie", s. 222.

18 Zob. WASIK, Budownictwo zamkowe na ziemi chetmińskiej, s. 271-304, 317-322; ID., „Techniki budowy zamków w typie kasztelu w państwie krzyżackim w Prusach", Ochrona Zabytków 71, nr 2 (2018), s. 33-60.

191 stopa nowej miary to $28,8 \mathrm{~cm}$, a 1 pręt to 15 stóp.
} 


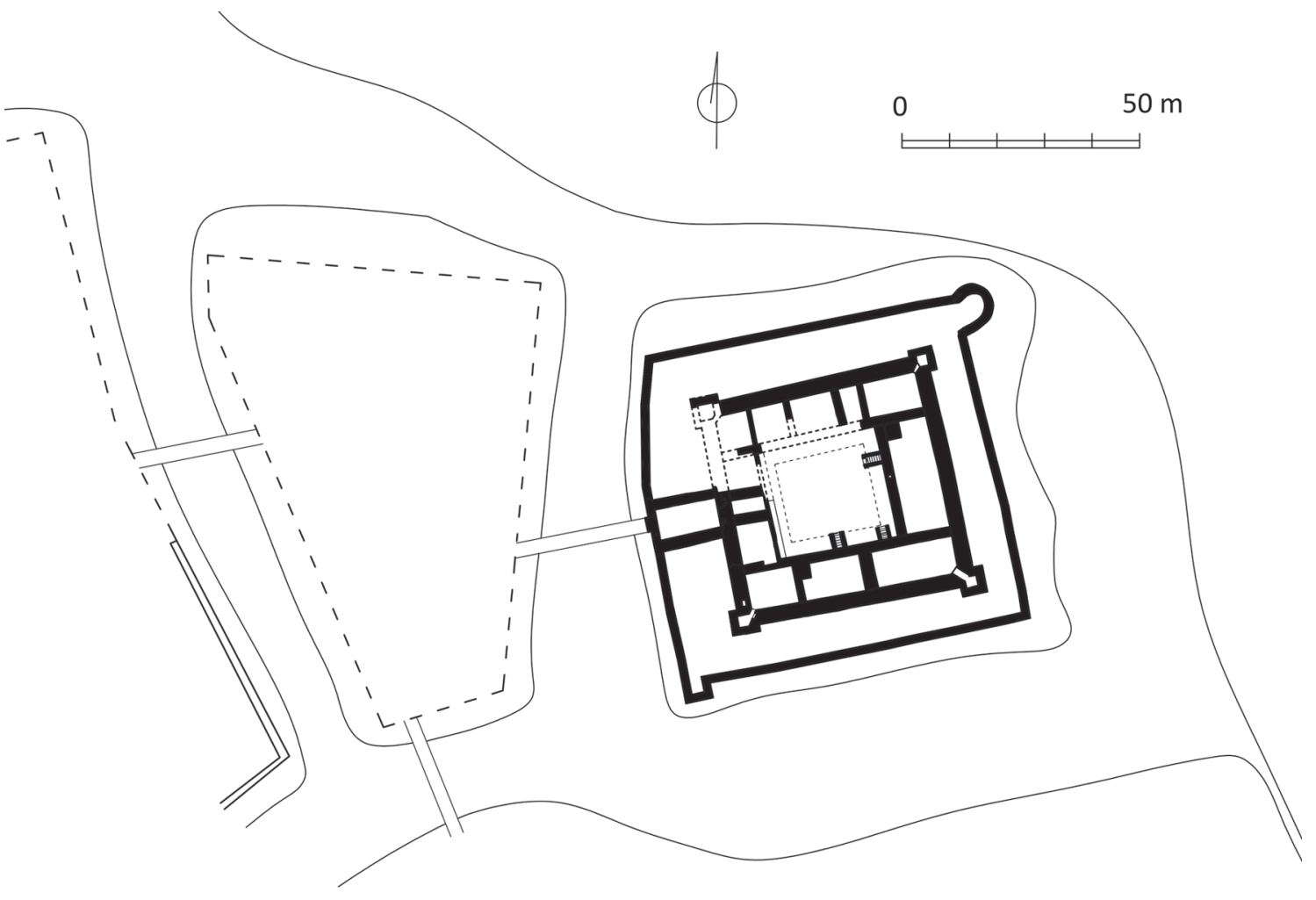

3. Lubawa, rzut zamku wedtug badań z lat 1998-2001 i 2015-2016. Rys. Bogusz Wasik

łącznie z kurtyną obwodową. Ściany skrzydła południowego i zachodniego (włącznie z działowymi) są także przewiązane, co wskazuje, że budowano je łącznie, a nie po kolei. Brak zachowanego węzła architektonicznego nie pozwala jednak przesądzić, czy ściany skrzydeł dostawiono do kurtyny obwodowej w kolejnym etapie, czy zbudowano je łącznie. W dalszej kolejności dostawiono bez wątpienia ganek. Kończąc charakterystykę zamku w Wąbrzeźnie należy zwrócić uwagę na słaby poziom detalu architektonicznego. Pomijając cegłę fryzu maswerkowego, profilowane kształtki żebrowe zastosowane na zamku cechują się bowiem niedbałością, wręcz prymitywizmem formy ${ }^{20}$.

Kolejnym zamkiem biskupów chełmińskich była warownia w Lubawie, która stała się ich główną siedzibą. Pierwsza, jeszcze drewniano-ziemna, powstała około połowy XIII w. Utożsamiać ją zapewne można z gródkiem stożkowatym, znajdującym się w zachodniej części miasta ${ }^{21}$. Sam zamek, jak wykazały badania, nie powstał w miejscu starszego obiektu obronnego, a jedynie niezbyt intensywnego osadnictwa. Brak źródeł wskazujących na początek budowy. W literaturze przyjął się pogląd, że inwestycję rozpoczął biskup Herman von Prizna. W rzeczywistości pierwsza wzmianka o zamku zawarta jest w odnowionym dokumencie lokacyjnym miasta, wystawionym w 1326 r. przez biskupa Ottona. Wtedy już zamek w jakiejś postaci (nieukończonej) istniał, gdyż w nim został ów akt wystawiony. Osąd o rozpoczęciu budowy przez biskupa Hermana opierał się na fak-

\footnotetext{
${ }^{20}$ Maciej Majewski, Bogusz WAsik, Marcin Wiewióra, ,Studia nad warsztatem budowlanym zamku biskupów chełmińskich w Wąbrzeźnie", Wiadomości Konserwatorskie 38 (2014), s. 60; WAsIK, Budownictwo zamkowe na ziemi chełmińskiej, s. 111-114, 229-230; Aneksy, s. 21, ID., „Próba rekonstrukcji etapów budowy i układu przestrzennego zamku”, s. 207-211.

${ }^{21}$ Aleksander ANDRZEJEwski, Leszek KAJZER, Marcin LewANDOwSKI, „Dzieje warowni w świetle dotychczasowych badań”, w: Zamek w Lubawie. Dawniej i dziś, red. Leszek KaJzer (Lubawa: Urząd Miasta, 2001), s. 15.
} 
4. Lubawa, rekonstrukcja zamku wysokiego w połowie $X V$ w. wedtug Leszka Kajzera z korekta Bogusza Wasika

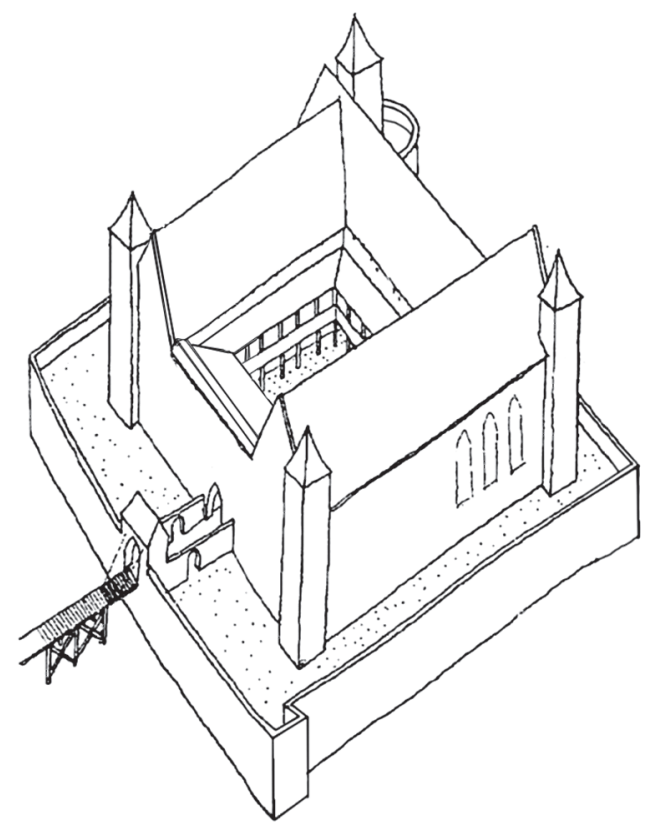

cie, że ten dokonał pierwszej lokacji miasta, która wymagała następnie odnowienia ${ }^{22}$. Został być może też zasugerowany tym, że biskup ten rozpoczął budowę zamku w Wąbrzeźnie. Zawierający tę ostatnią informację katalog biskupów chełmińskich milczy jednak na temat Lubawy. Oba te zamki różnią się zresztą diametralnie pod względem formalnym i warsztatowym. Po śmierci biskupa nastąpiła niemal dekada wakatu na stanowisku, co musiało podjęte działania, w tym akcję lokacyjna, spowolnić lub nawet przerwać. Same cechy formalne zamku, które są w tej sytuacji istotnym źródłem, przeczą wczesnej chronologii. Budowla od początku nie nawiązywała do wczesnych kaszteli chełmińskich, ale podobnie jak zamek w Kwidzynie do tzw. klasycznych kaszteli krzyżackich. Wskazują na to takie cechy, jak znaczna kubatura (plan zbliżony do kwadratu o bokach długości od ok. 51 do 54,5 m) i artykulacja narożników wyraźnie wysuniętymi, niemałymi wieżami, mieszczącymi pomieszczania ${ }^{23}$ (il. 3). Trudno więc przyjąć, by zamek w Lubawie wyprzedził chronologicznie wzorcowe dla tego typu kasztelu zamki w Radzyniu Chełmińskim i Brodnicy ${ }^{24}$. Na tej podstawie rozpoczęcie budowy lubawskiego zamku musiało przypaść na drugie - trzecie dziesięciolecie XIV w., a więc nic nie wskazuje, by nastąpiło

\footnotetext{
22 Aleksander AndRzeJewski, Leszek KAJZER, Marcin LewANDOwski, „Badania archeologiczno-architektoniczne prowadzone w latach 1998-2000", w: Zamek w Lubawie. Dawniej i dziś, s. 70; Johannes HeISE, Der Kreis Löbau (Danzig: Kommissions-Verl. von Th. Bertling, 1895), s. 636-637 (Die Bau- und Kunstdenkmäler der Provinz Westpreussen, 10); Marc JARZEBowski, Die Residenzen der Preussischen Bischöfe bis 1525 (Toruń: Wydawnictwo Naukowe UMK, 2007), s. 23 (Prussia Sacra, 3)

${ }^{23} \mathrm{Na}$ podstawie tych cech formalnych nie można się tu zgodzić z opinią, według której zamek w Lubawie przypomina dom konwentu w Papowie Biskupim, co ma przemawiać za jego wczesną chronologią; zob. Leszek KaJzer, „Siedziba biskupów chełmińskich w Lubawie na tle budownictwa Państwa Krzyżackiego w Prusach", w: Zamek w Lubawie. Dawniej i dziś, red. Leszek KaJzer (Lubawa: Urząd Miasta, 2001), s. 123-124. Ten ostatni miał mniejszy, charakterystyczny dla wczesnych kaszteli konwentualnych rozmiar, a ryzalitowe wieżyczki były nieduże i nie mieściły pomieszczeń. Podobieństwa między zamkiem w Lubawie a domami konwentów w Radzyniu Chełmińskim i Brodnicy są o wiele bardziej wyraźne. Podstawowa różnica między nimi polega na braku bergfriedu, ale biorąc pod uwagę pozostałe cechy traktować ją należy jako drugorzędną.

24 TorBus, Zamki konwentualne państwa krzyżackiego s. 167-202; WASIK, Budownictwo zamkowe na ziemi chetmińskiej, s. 298-299, 303-304, 310.
} 


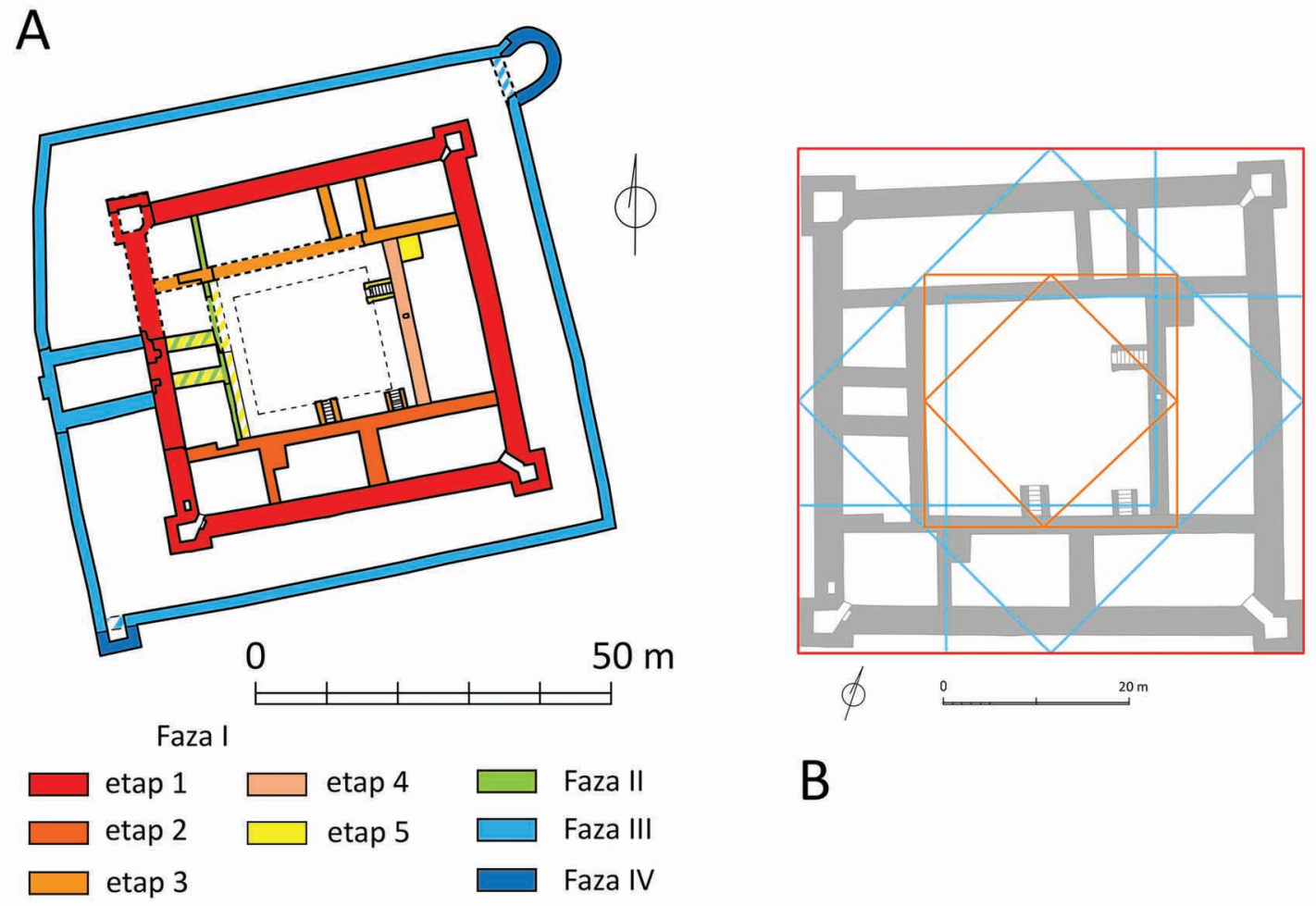

5. Lubawa, rzut zamku wysokiego (kasztelu): A - fazy i etapy budowy; B - rozrys ad quadratum. Rys. Bogusz Wasik

to za biskupa Hermana von Prizna, ale najpewniej za sprawą biskupa Mikołaja Afri (13191323) i jego następcy - Ottona ${ }^{25}$.

Zamek w Lubawie był dwuczłonową budowlą, składającą się z przedzamcza (od zachodu) i zamku wysokiego (od wschodu; il. 3). Warto podkreślić, że z mapy z $1820 \mathrm{r}^{26}$ wynika, iż przedzamcze, wbrew dotychczasowym rekonstrukcjom, było oddzielone od miasta fosą ${ }^{27}$. Kasztel, główny człon założenia, wzniesiony został na planie zbliżonym do kwadratu z czterema narożnymi wysuniętymi wieżami. Nie miał natomiast wieży głównej $^{28}$ (il. 4). Wjazd znajdował się na osi skrzydła zachodniego. Założenie planowano od początku jako czteroskrzydłowe, jednak zachodniego początkowo nie zrealizowano, poprzestając tylko na wykonaniu fundamentów. Trójskrzydłowe założenie zostało zrealizowane w zasadniczym zrębie bez wattpienia za biskupa Ottona (1323-1349), ale prace wykończeniowe mogły trwać jeszcze za biskupa Wikbolda Dobilsteina (1363-1385). Niewzniesione zgodnie z pierwotnym planem skrzydło zachodnie uzupełnił dopiero biskup Arnold Stapil (1402-1416) ${ }^{29}$. Ponieważ otrzymało ono wyjątkowo cienkie ściany (ok. 0,7 m

\footnotetext{
${ }^{25}$ Chronologię tę pośrednio potwierdza fakt stosowania do budowy kościoła farnego św. Anny, datowanej na 2. i 3. ćwierć XIV w., cegieł o podobnym rozmiarze i analogicznych form detali ceramicznych jak w zamku; HerRmanN, Mittelalterliche Architektur im Preussenland, s. 569; WAsIK, Budownictwo zamkowe na ziemi chetmińskiej, s. 157; Aneksy, s. 29. ${ }^{26}$ Mapa opublikowana w: Christofer HerRmAnn, Zamki w państwie krzyżackim w Prusach. Kompendium zamków krzyżackich i biskupich (Olsztyn: Artes, 2015), s. 196; oryginał w Geheimes Staatsarchiv PK, Berlin.

${ }^{27}$ Zob. ANDRZEJEwSKI, KaJZer, LewandowsKI, „Badania archeologiczno-architektoniczne prowadzone w latach 19982000", s. 72-73; WASIK, Budownictwo zamkowe na ziemi chetmińskiej, s. 311.

${ }^{28}$ Północno-zachodnia z czterech wież narożnych została wtórnie podwyższona w nowożytności; zob. ANDRzeJewSKI, KAJZER, LEWANDOWSKI, „Badania archeologiczno-architektoniczne prowadzone w latach 1998-2000”, s. 72.

${ }^{29}$ Ibid., s. $70-71$.
} 


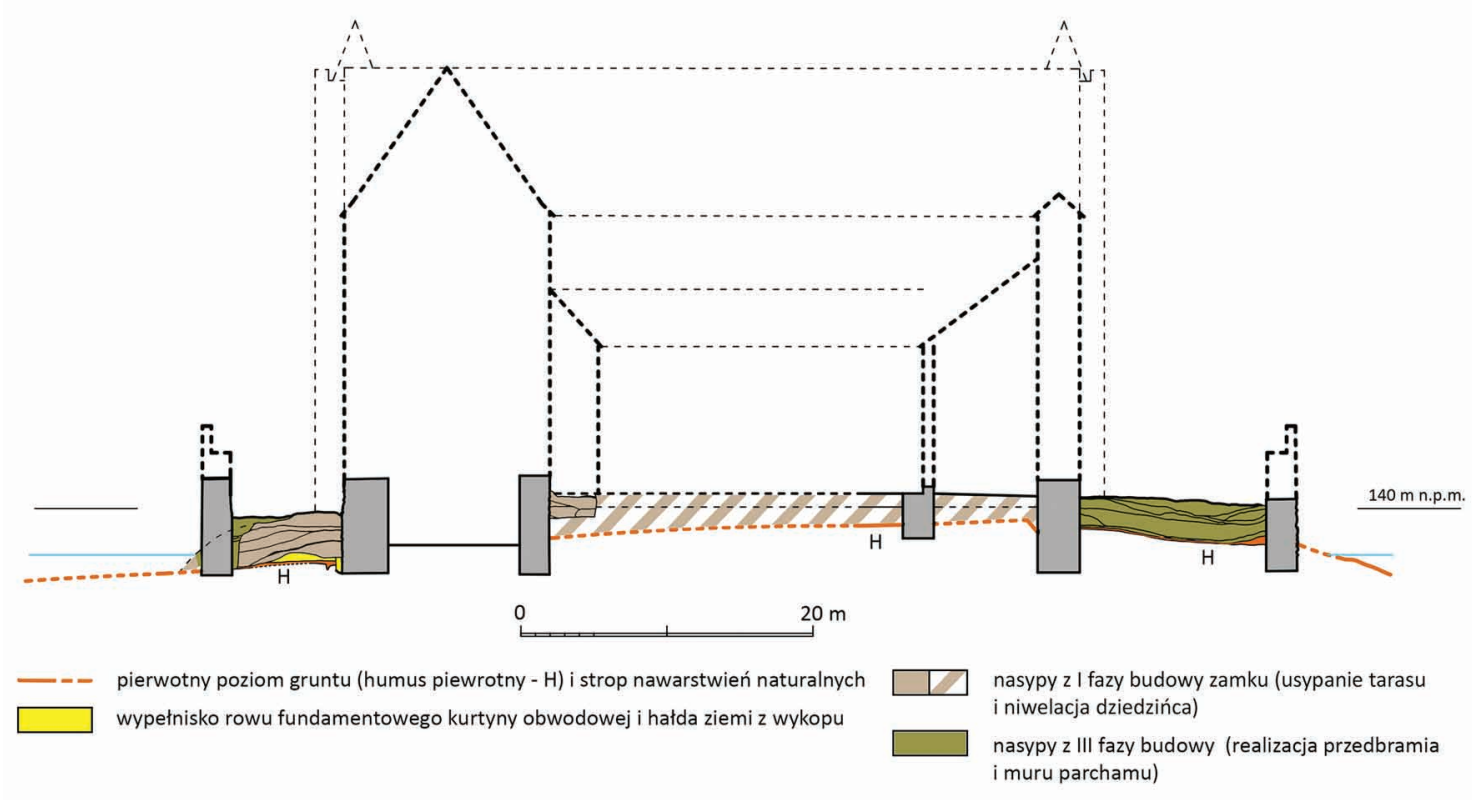

6. Lubawa, przekrój zachód-wschód (widok na południe) zamku wysokiego z zaznaczeniem poziomu gruntu sprzed budowy i nasypów z I i III fazy wedtug badań Leszka Kajzera i Adama Mackiewicza z lat 1998-2001 i 2015-2016. Rys. Bogusz Wasik

- w porównaniu do planowanych dwóch metrów), wątpliwym wydaje się, by skrzydło to miało wysokość równą trzem starszym. Przy tej grubości, jeżeli skrzydło miało piętro, to mogło być ono wykonane z muru pruskiego. Nowożytne inwentarze wymieniają szereg pomieszczeń, ale bardzo trudno przyporządkować je do poszczególnych skrzydeł. Wniosek o mniejszych gabarytach skrzydła zachodniego może wspierać jednak fakt, że w inwentarzu z 1661 r. wizytatorzy opisujący kolejne pomieszczenia pierwszego piętra jako do ostatniego przechodzą do „trzeciego kwadratu ganku” ${ }^{30}$, co wskazuje, że zamek nie miał krużganka z czterech stron i brakowało go najpewniej właśnie od zachodu. Na to, że skrzydło to nie dorównywało pozostałym, wskazuje ponadto fakt, że jego dach nie jest widoczny na panoramie miasta z 2. połowy XVII w., przedstawionej na obrazie z kościoła w Lipach ${ }^{31}$.

Wskazanie układu funkcjonalnego pomieszczeń jest trudne, gdyż inwentarze nie pozwalają sprecyzować lokalizacji opisywanych wnętrz, a ponadto przedstawiają zamek po nowożytnych przebudowach ${ }^{32}$. Podział wertykalny zamku wpasowuje się w standardy. Początkowo wszystkie skrzydła miały być podpiwniczone, ale w związku z niezrealizowaniem zachodniego w pierwotnie planowanej formie, jego piwnica została jeszcze w średniowieczu zasypana ${ }^{33}$. Piwnice i parter pełniły funkcje zaplecza gospodarczego. Najpewniej w skrzydle północnym i wschodnim znajdował się browar, piekarnia i kuchnia ${ }^{34}$.

\footnotetext{
${ }^{30}$ Aleksander ANDRZEJEwSKi, Leszek KAJZER, Marcin LEWANDOwSKI, „Nieznany inwentarz zamku z 1661 roku”, w: Zamek w Lubawie. Dawniej i dziś, s. 29.

${ }^{31}$ Przerys panoramy na wklejce w: Gustaw LIEK, Die Stadt Löbau in Westpreussen mit Berücksichtigung des Landes Löbau (Marienwerder: Im Verlage des Historischen Vereins, 1892).

32 AndrZeJewski, KAJZER, LewANDOwsKi, „Badania archeologiczno-architektoniczne prowadzone w latach 1998-2000”, s. $72-73$.

33 Ibid., s. 46-53.

34 AnDRZeJewski, KaJzer, LewANDOwski, „Nieznany inwentarz zamku z 1661 roku”, s. 25; Inwentarz dóbr biskupstwa chetmińskiego z r. 1614 z uwzględnieniem późniejszych do roku 1759, wyd. Alfons MańKowski (Toruń: Towarzystwo
} 
Zapewne z piecem w którymś z tych pomieszczeń należy łączyć cokół odkryty w rogu piwnicy skrzydła wschodniego ${ }^{35}$ (il. 3, 5). Wnętrza reprezentacyjne i mieszkalne zajmowały piętro. Główne było skrzydło południowe, którego wschodnią salę zajmowała kaplica. Najpewniej z sąsiadującym z nią refektarzem łączyć należy cokół pieca (hypocaustum), odkryty w rogu środkowej piwnicy skrzydła ${ }^{36}$. Od strony dziedzińca były drewniane ganki, które w nowożytności przynajmniej po części wykonane były z muru pruskiego ${ }^{37}$.

Badania archeologiczne dostarczyły wiele danych na temat techniki budowy zamku ${ }^{38}$. Ostatnie wniosły ponadto informacje i źródła, istotnie modyfikujące dotychczas przyjęte poglądy na temat etapów budowy zamku ${ }^{39}$. Nie przeprowadzono co prawda rozwarstwienia architektonicznego murów pod tym kątem, ale wykonana dokumentacja fotograficzna i rysunkowa to umożliwia ${ }^{40}$ (il. 5: A). Okazuje się, że wbrew wcześniejszym wnioskom ścian kurtyny obwodowej kasztelu, skrzydeł i muru parchamu nie budowano jednocześnie ${ }^{41}$.

Naukowe w Toruniu, 1927), s. 6-7 (Fontes, 22); Inwentarze dóbr biskupstwa chetmińskiego (1646 i 1676), wyd. Ryszard Mienicki (Toruń: Towarzystwo Naukowe w Toruniu, 1955), s. 5-6 (Fontes, 40); Inwentarze dóbr biskupstwa chetmińskiego (1723-1747), wyd. Ryszard Mienicki (Toruń: Towarzystwo Naukowe w Toruniu, 1956), s. 126-127 (Fontes, 42).

${ }^{35}$ Bartłomiej KaCZYŃSKi, Adam Mackiewicz, Iwona ZduŃSKA, „Badania archeologiczne zamku biskupów chełmińskich w Lubawie w latach 2015-2016", w: Materiaty do archeologii Warmii i Mazur, t. 2, red. Sławomir WadYL, Maciej KARCZEWSKI, Mirosława HofFMANN (Warszawa-Białystok-Olsztyn: Instytut Archeologii Uniwersytetu Warszawskiego, Wydział Historyczno-Socjologiczny Uniwersytetu w Białymstoku, Instytut Historii i Stosunków Międzynarodowych Uniwersytetu Warmińsko-Mazurskiego w Olsztynie, 2018), s. 350; Adam MackiEwicz, Bartłomiej KaczyŃski, Sprawozdanie z badań archeologicznych poludniowego, wschodniego, fragmentu pótnocnego skrzydta, przedbramia, parchamu oraz drogi dojazdowej zamku biskupów chetmińskich w Lubawie, st. II (AZP 30-54/42), wykopy XIIIa-XVa, XVI-XXIV, pow. iławski, woj. warmińsko mazurskie, t. 1: Część analityczna, Olsztyn 2016, s. 56, maszynopis w archiwum WUOZ w Olsztynie, Delegatura w Elblagu, sygn. EMO471.

${ }^{36}$ ANDRZEJEWSKI, KAJZER, LewANDOWSKI, „Nieznany inwentarz zamku z 1661 roku”, s. 28; Inwentarz dóbr biskupstwa chetmińskiego z r. 1614, s. 9-11; Inwentarze dóbr biskupstwa chetmińskiego (1646 i 1676), s. 10, 78-79; Inwentarze dóbr biskupstwa chetmińskiego (1723-1747), s. 125-126; JARZEBOwsкi, Die Residenzen der Preussischen Bischöfe bis 1525, s. 26-27; KACZYŃSKI, MACKIEWICZ, ZDUŃSKA, „Badania archeologiczne zamku biskupów chełmińskich w Lubawie w latach 2015-2016", s. 349; MACKIEwICZ, KACZYŃSKI, Sprawozdanie z badań archeologicznych potudniowego, wschodniego, fragmentu pótnocnego skrzydła, przedbramia, parchamu oraz drogi dojazdowej zamku biskupów chetmińskich w Lubawie, t. 1, s. 53.

${ }^{37}$ Inwentarze dóbr biskupstwa chetmińskiego (1646 i 1676), s. 79.

${ }^{38}$ Zob. cytowaną wcześniej pracę pod red. Leszka Kajzera Zamek w Lubawie. Dawniej i dziś.

${ }^{39}$ KACZYŃSKi, MACKIEWICZ, ZDuŃSKA, ,Badania archeologiczne zamku biskupów chełmińskich w Lubawie w latach 20152016", s. 343-358; MACKIEWICZ, KACZYŃSKI, Sprawozdanie z badań archeologicznych poludniowego, wschodniego, fragmentu pótnocnego skrzydła, przedbramia, parchamu oraz drogi dojazdowej zamku biskupów chetmińskich w Lubawie. ${ }^{40}$ Mackiewicz, KaCzyŃsKi, Sprawozdanie z badań archeologicznych południowego, wschodniego, fragmentu pótnocnego skrzydła, przedbramia, parchamu oraz drogi dojazdowej zamku biskupów chełmińskich w Lubawie; EID., Sprawozdanie z badań archeologicznych poludniowego, wschodniego, fragmentu pótnocnego skrzydta, przedbramia, parchamu oraz drogi dojazdowej zamku biskupów chetmińskich w Lubawie, st. II (AZP 30-54/42), wykopy XIIIa-XVa, XVI-XXIV, pow. iławski, woj. warmińsko mazurskie, t. 2: Dokumentacja fotograficzna, Olsztyn 2016, maszynopis w archiwum WUOZ w Olsztynie, Delegatura w Elblagu, sygn. EMO472; EID., Sprawozdanie z badań archeologicznych potudniowego, wschodniego, fragmentu pólnocnego skrzydła, przedbramia, parchamu oraz drogi dojazdowej zamku biskupów chetmińskich w Lubawie, st. II (AZP 30-54/42), wykopy XIIIa-XVa, XVI-XXIV, pow. iławski, woj. warmińsko mazurskie, t. 3: Dokumentacja rysunkowa, Olsztyn 2016, maszynopis w archiwum WUOZ w Olsztynie, Delegatura w Elblągu, sygn. EMO473; EID., Sprawozdanie z badań archeologicznych południowego, wschodniego, fragmentu pótnocnego skrzydła, przedbramia, parchamu oraz drogi dojazdowej zamku biskupów chetmińskich w Lubawie, st. II (AZP 30-54/ 42), wykopy XIIIa-XVa, XVI-XXIV, pow. iławski, woj. warmińsko mazurskie, t. 4: Dokumentacja rysunkowa, Olsztyn 2016, maszynopis w archiwum WUOZ w Olsztynie, Delegatura w Elblągu, sygn. EMO474.

${ }^{41}$ ANDRZEJEwSKI, KAJZER, LewANDOWSKI, „Badania archeologiczno-architektoniczne prowadzone w latach 1998-2000”, s. 70-71. Błędny ten wniosek przyjął wówczas też autor niniejszego artykułu; zob. WASIK, Budownictwo zamkowe na ziemi chetmińskiej, s. 311. 
Przyglądając się węzłom architektonicznym widzimy wyraźnie, że w etapie I inwestycji wymurowano kurtynę obwodową z narożnymi wieżami, do której w etapie II dostawiono ściany skrzydła południowego. W etapie III (ewentualnie równolegle z II, gdyż trudno to przesądzić z powodu braku styku murów) zaczęto budować skrzydło północne, a w IV krótkie wschodnie. Na końcu wzniesiono ściany fundamentowe skrzydła zachodniego ${ }^{42}$. Wskazane etapy określić można jako I fazę budowy zamku, którą przerwano, gdyż nie zrealizowano skrzydła zachodniego powyżej gruntu. Zbudowano je dopiero później, według zmienionej koncepcji (faza II). Etapowanie to należy traktować jako kolejność realizacji zaplanowanej inwestycji. Potwierdza to analiza rzutu zamku pod kątem stosowania geometrycznych metod projektowania. Wskazuje ona, że od początku wyznaczono proporcje skrzydeł, stosując metodę ad quadratum (il. 5: B). Jej wykorzystanie można zaobserwować także w przypadku kaszteli krzyżackich. Polegała ona na tym, że modułem do pobierania pomiarów były kolejne, wpisywane w siebie kwadraty, z których pierwszy (bazowy) wyznaczał obrys kasztelu, a kolejne szerokości skrzydeł i dziedzińca. Na podstawie tych wielkości wyznaczano rzut poziomy, a w niektórych wypadkach także wysokości budowli ${ }^{43}$.

Mury zamku wzniesiono w wąskoprzestrzennych rowach fundamentowych ${ }^{44}$. Analizując pierwotny układ terenu stwierdzić można, że piwnice posadowiono mniej więcej na jego poziomie (il. 6). Po wzniesieniu ścian przynajmniej do pewnej wysokości wykonano też wielkie prace ziemne o charakterze nasypowym. W ich efekcie piwnice uległy zagłębieniu. Na dziedziniec naniesiono około 2-2,5 m gliny, wyrównując jego poziom. Usypano też znaczne gliniane tarasy po zewnętrznej stronie murów kasztelu, o miąższości ok. 2,5-3,3 $\mathrm{m}^{45}$. Autorzy ostatnich badań archeologicznych zmienili jednak diametralnie wcześniej przyjętą chronologię budowy parchamu. Okazało się bowiem, że jego mur został wzniesiony w wąskoprzestrzennym wykopie, przecinającym nawarstwienia opisanego wcześniej tarasu ${ }^{46}$. Wskazuje to, że w ramach I fazy budowy zamku wykonano sam taras, który miał najpewniej zbocza pod kątem około $45^{\circ}$, jakie znamy z zamku w Papowie Biskupim i pierwszych etapów budowy zamków w Radzyniu Chełmińskim i Świe$\mathrm{ciu}^{47}$. Co ciekawe, podczas ostatnich badań nie stwierdzono, żeby taras taki wykonany był

\footnotetext{
${ }^{42} \mathrm{Na}$ dostawienie ściany piwnicy skrzydła zachodniego do południowego zwrócono uwage już podczas poprzednich badań; zob. ANDRZEJEWSKI, KAJZER, LEWANDOWSKI, „Badania archeologiczno-architektoniczne prowadzone w latach 19982000", s. 52.

${ }^{43}$ Szczegółowo na ten temat zob. WASIK, Budownictwo zamkowe na ziemi chetmińskiej, s. 49-61; ID., „Metoda projektowania zamków konwentualnych na ziemi chełmińskiej. Przyczynek do badań nad zastosowaniem kwadratury w krzyżackim budownictwie zamkowym", Kwartalnik Architektury i Urbanistyki 58, nr 4 (2012), s. 79-91.

${ }^{44} \mathrm{~W}$ profilu wykopu na wschodnim parchamie dostrzec można nawet hałdę ziemi wyrzuconej z rowu fundamentowego.

45 ANDRZEJEWSKI, KAJZER, LEWANDOWSKI, „Badania archeologiczno-architektoniczne prowadzone w latach 1998-2000”, s. 42-71; WAsiK, Budownictwo zamkowe na ziemi chetmińskiej, s. 310-311.

${ }^{46}$ Założony przez zespół Adama Mackiewicza wykop na parchamie wschodnim był zlokalizowany w bezpośrednim sąsiedztwie starszego wykopu z badań pod kierunkiem Leszka Kajzera. Układ nawarstwień z obu wykopów jest zgodny, jednak w wykonanym wcześniej przez zespół z Uniwersytetu Łódzkiego zaprzestano zbyt wcześnie eksploracji przy murze parchamu, przez co nie odkryto rowu fundamentowego (odkrytego przez zespół Mackiewicza). Brak tego istotnego szczegółu przesądził o błędnej interpretacji poczynionej przez zespół Leszka Kajzera; zob. ANDRZEJEWSKI, KAJZER, LEWANDOWSKI, „Badania archeologiczno-architektoniczne prowadzone w latach 1998-2000”, s. 42-45; KACZYŃSKI, MACKIEWICZ, ZDUŃSKA, „Badania archeologiczne zamku biskupów chełmińskich w Lubawie w latach 2015-2016”, s. 351; MACKIEWICZ, KACZYŃSKI, Sprawozdanie z badań archeologicznych poludniowego, wschodniego, fragmentu pólnocnego skrzydła, przedbramia, parchamu oraz drogi dojazdowej zamku biskupów chetmińskich w Lubawie, t. 1, s. 71-73.

${ }^{47}$ WASIK, Budownictwo zamkowe na ziemi chetmińskiej, s. 95-98, 105-107; ID., „Techniki budowy zamków w typie kasztelu”, s. 41, 46; ID., „Zamek w Świeciu. Topografia i technika budowy zamku krzyżackiego”, Komunikaty Mazursko-Warmińskie 2 (2018), s. 228-231.
} 
od zachodu (w linii bramy). Dopiero później (faza III) podjęto decyzję o budowie muru parchamu, posadawiając go w linii dawnego stoku i wyrównując taras parchamu nasypem (ryc. 5: A, 6). Wraz z parchamem wzniesiono też szyję bramną i wykonano w jej przestrzeni nasyp o grubości 2-2,6 $\mathrm{m}^{48}$. Autorzy badań, na podstawie ceramiki zalegającej w zasypisku rowu fundamentowego muru parchamu, wydatowali jego budowę na połowę $\mathrm{XV} \mathrm{w.}{ }^{49}$ Taka chronologia wydaje się jednak zbyt późna, gdyż czworoboczny parcham, pozbawiony w tej fazie baszt, byłby wówczas założeniem anachronicznym. Wydaje się więc, że bardziej prawdopodobne jest lokowanie tej inwestycji bliżej początku XV w. lub w związku z wojnami toczącymi się w ciagu pierwszych trzech dekad wieku XV. Teza ta staje się bardziej przekonywająca, kiedy weźmiemy pod uwagę kolejną - IV fazę rozbudowy zamku, polegającą na dostawieniu do parchamu potężnej baszty ogniowej w narożniku północno-wschodnim, jak i trójściennej od południowego zachodu. Fazę tę datuje się bowiem na 2. ćwierć - połowę XV w. (przed wojną trzynastoletnią) $)^{50}$.

W obrębie dominium diecezji pomezańskiej kasztelową formę otrzymał nie zamek biskupów, ale kapituły. Zamek w Kwidzynie jest lepiej zachowany od poprzednich, ale od końca XVIII w. uległ istotnym przekształceniom i przebudowom. Najpierw rozebrano dwa skrzydła, a dalsze zmiany związane były z adaptacją budynku na sąd. Od połowy XIX w. zaczęto powolne prace restauratorskie. Odbudowano wówczas m.in. wszystkie sklepienia pierwszego piętra (w pełni oryginalne zachowały się tylko w pomieszczeniu nad bramą) oraz zachodnie ramię krużganka (oryginalne pozostało północne). Podwyższono wówczas także dwie narożne wieże, które były obniżone do poziomu ścian skrzydeł zapewne jeszcze w końcu XV w. ${ }^{51}$, przy czym nadano im zapewne wysokość większą niż miały pierwotnie $^{52}$. Obiekt tworzy zwarty i wyjątkowy w swoim rodzaju zespół zamkowo-katedralny, złożony z przedzamcza i zamku wysokiego połączonego z katedrą. Nasze rozważania skupimy jednak tylko na zamku wysokim w typie kasztelu.

Utworzona w $1284 \mathrm{r}$. kapituła rezydowała początkowo zapewne na zamku biskupim, a później w domu w mieście. Grunt pod zamek zakupiła za czasów biskupa Ludeko (1309-1321), a z 1334 r. pochodzi pierwszy dokument wystawiony na zamku, co świadczy, że w jakiejś postaci musiał już wówczas istnieć. Ponieważ korpus katedry został dostawiony do wschodniej elewacji kasztelu wtórnie, co wymusiło zamurowane znajdujących się tam okien, prace na zamku musiały być co najmniej zaawansowane w momencie rozpoczęcia budowy nawy kościoła. Według nowych ustaleń, podpartych m.in. dendrochronologią więźby, chór zaczęto wznosić w 1343 r., a korpus budowano od połowy stule-

\footnotetext{
${ }^{48}$ MaCKIEWICZ, KACZYŃSKI, Sprawozdanie z badań archeologicznych poludniowego, wschodniego, fragmentu pótnocnego skrzydła, przedbramia, parchamu oraz drogi dojazdowej zamku biskupów chetmińskich w Lubawie, t. 1, s. 77-78.

${ }^{49}$ Badacze próbowali łączyć też inwestycję z wojną trzynastoletnią; KACZYŃSKi, MACKIEwicz, ZduŃsKA, „Badania archeologiczne zamku biskupów chełmińskich w Lubawie w latach 2015-2016”, s. 351.

${ }^{50}$ Aleksander ANDRZEJEwSKi, Leszek KAJZER, „,The Chelmno bishops' castle in Lubawa in the light of the latest research”, w: Castella Maris Baltici, t. 6, red. Albinas KunceviČıus (Vilnius: Savastis, 2004), s. 20 (Archaeologia medii aevi Finlandiae, 7); ANDRZEJEWSKI, KAJZER, LEWANDOWSKI, „Badania archeologiczno-architektoniczne prowadzone w latach 1998-2000”, s. 71; Agata Wojciechowska-Grygo, Leszek Wawrykiewicz, Jerzy Sikorski, Wstępne badania architektoniczne zewnętrznych murów obronnych zamku biskupów chełmińskich w Lubawie, Lubawa-Olsztyn 2008, s. 14-17, maszynopis w archiwum WUOZ w Olsztynie, Delegatura w Elblągu, sygn. 7007.

${ }^{51}$ Obniżono je być może już w ramach prac remontowych przeprowadzonych w 1487 r., usuwających zniszczenia wojenne. Na widoku z 1595 r. (wg Caspara Hennebergera) obie nie mają już swojej pierwotnej wysokości, którą zachowała jedynie nieistniejąca obecnie wieża południowo-zachodnia.

${ }^{52}$ Artur DoBRY, „Dziewiętnastowieczne prace restauratorskie w zespole zamkowo-katedralnym w Kwidzynie”, Komunikaty Mazursko-Warmińskie 1 (1994), s. 35-39.
} 


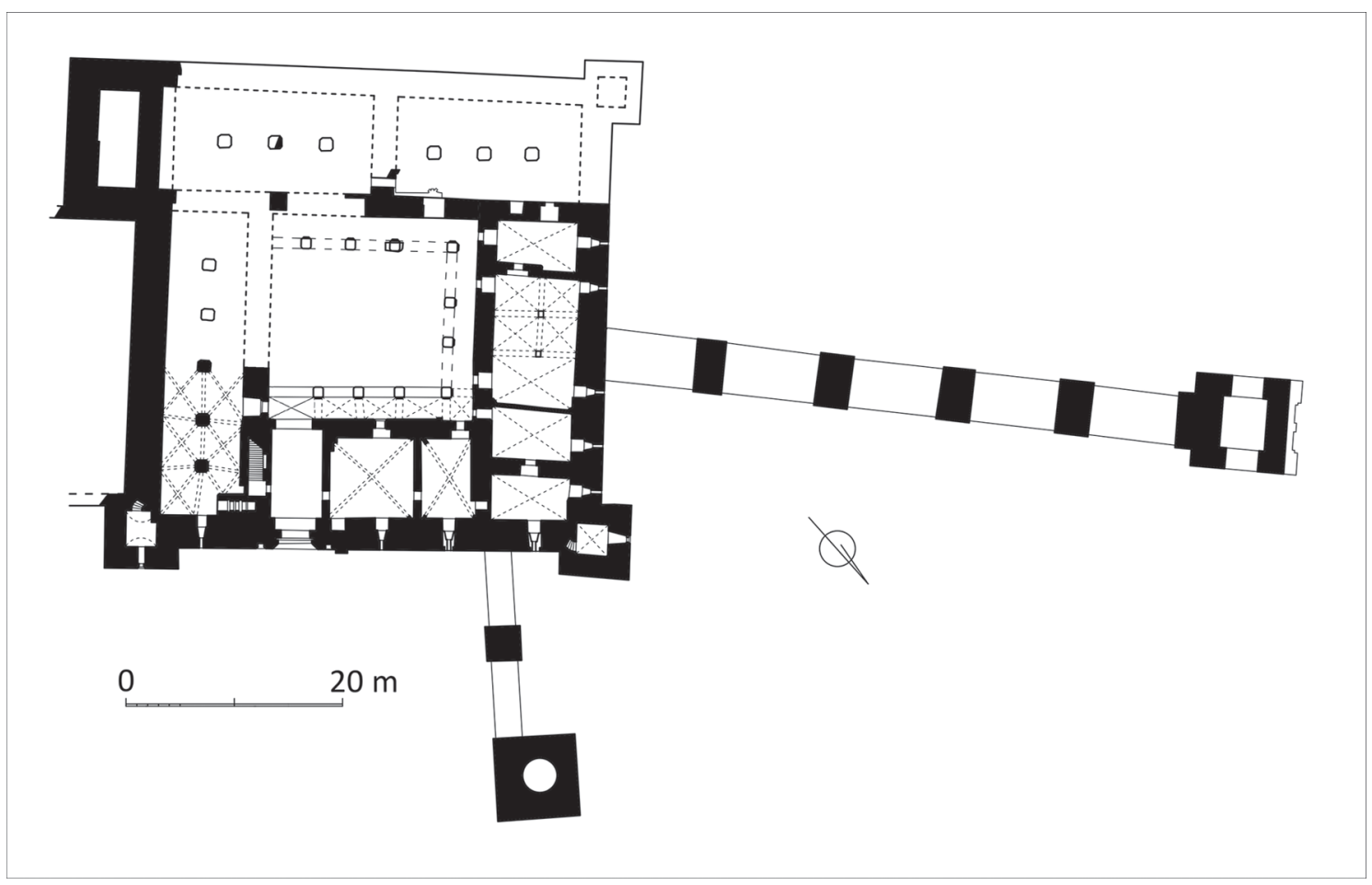

7. Lubawa, rekonstrukcja średniowiecznego rzutu parteru kasztelu. Rys. Bogusz Wasik wedtug badań Anny Chrzanowicz

cia do około 1380 r. Na tej podstawie czas realizacji zasadniczej formy kasztelu można wskazać na okres około 1320-1340. Chronologicznie i stylowo zamek wpasowuje się więc w typ. tzw. kasztelu klasycznego ${ }^{53}$.

Główny człon zamku stanowił kasztel na planie zbliżonym do kwadratu, o bokach długości około 48 m, z czterema podpiwniczonymi skrzydłami (il. 7). W trzech narożach znajdowały się wysunięte mniejsze wieże, zaś w czwartym (południowo-wschodnim) wieża główna na rzucie prostokąta. Nie był to bergfrid, ale, poza wieżą zamku wysokiego, jednocześnie dzwonnica katedry. Widać w tym nietypowym rozwiązaniu podobieństwo do Malborka, gdzie główna wieża także nie była stricte obronna, ale pełniła funkcję dzwonnicy przy kościele zamkowym. Zamek nie miał parchamu, ale od zachodu odchodzi od niego długim gankiem charakterystyczne gdanisko, a od północy wieża studzienna, dostępna przez krótszy ganek. Wjazd do kasztelu usytuowano niesymetrycznie w skrzydle północnym. Skrzydło wschodnie, w przeciwieństwie do pozostałych, nie miało dwuspadowego dachu, ale pulpitowy, oparty o szczyt katedry. Z tej strony nie było też krużganka, który to (murowany) był przy trzech pozostałych bokach dziedzińca. Elewacje skrzydła północnego i zachodniego oraz wież narożnych posiadają artykulacje smukłymi i wysokimi blendami. Na nieistniejącej elewacji południowej, jak wynika z ryciny Abrahama Boota (1627-1628), były dwie kondygnacje niskich blend, z których jedna zachowała się

\footnotetext{
${ }^{53}$ Clasen, Die mittelalterliche Kunst im Gebiete des Deutschordensstaates Preussen, s. 161; Christofer Herrmann, „Die pomesanische Kapitelsburg und der Dom in Marienwerder”, w: Burg und Kirche. Herrschaftsbau im Spannungsfeld zwischen Politik und Religion, red. Joachim Zeune, Hartmut Hofrichter (Würzburg: Deutsche Burgenvereinigung, 2013), s. 231-242; ID., Mittelalterliche Architektur im Preussenland, s. 593, 595; zob. też: Liliana Krantz, Jerzy DomaSŁowski, Katedra i zamek w Kwidzynie (Warszawa-Poznań-Toruń: PWN, 1982), s. 14-16, 22-24; Liliania KrantzDomasŁowsKa, „Katedra i zamek w Kwidzynie jako założenie obronne”, Folia Fromborcensia 1 (1992), s. 24; Bernhard Schmid, Die Domburg Marienwerder (Elbing: Preussenverlag, 1938), s. 3-6, 14.
} 

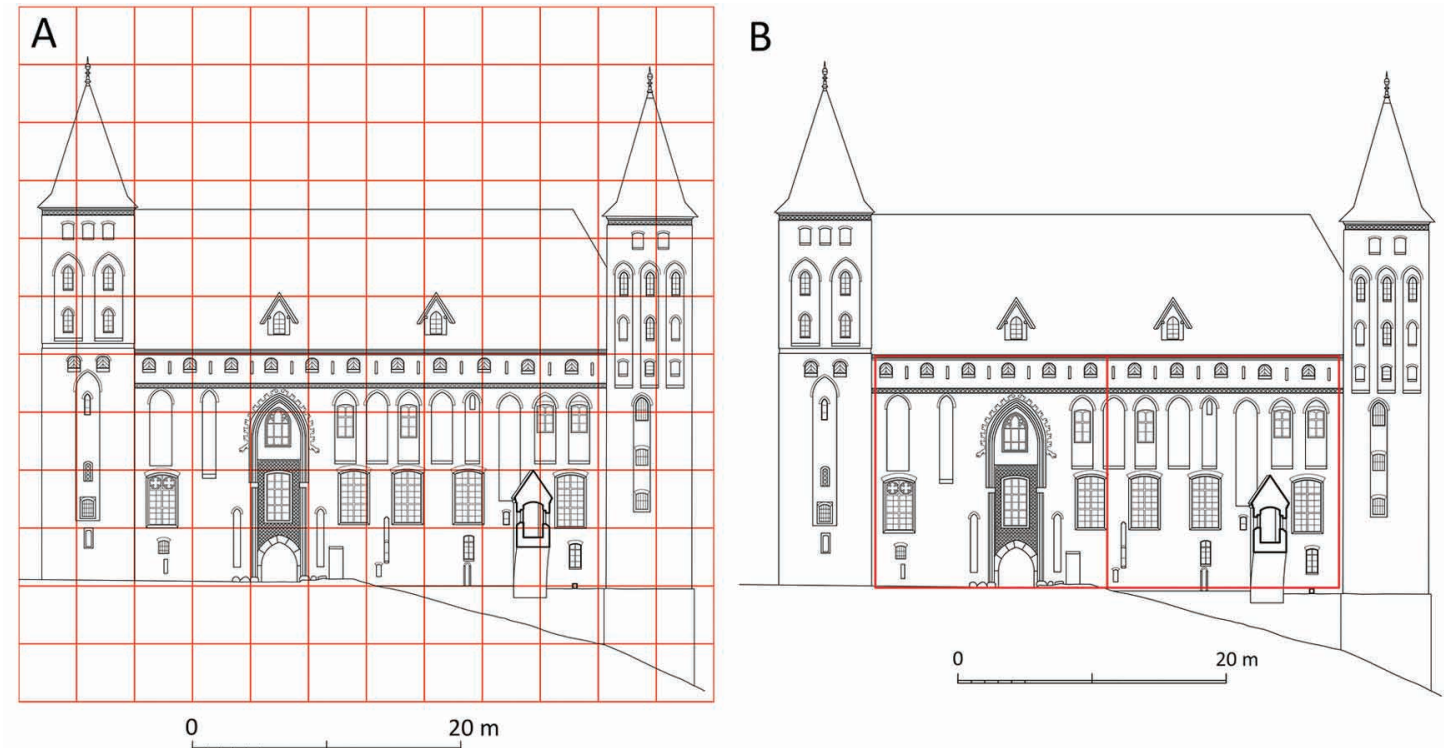

8. Kwidzyn, pótnocna elewacja kasztelu (stan po przebudowach z XIX-XX w.): $A$ - na siatce o module 1 pręta nowej miary chetmińskiej; $B$ - proporcje elewacji.

Oprac. Bogusz Wasik wedtug inwentaryzacji Ireny Jaroszewskiej-Bartoszewicz

w ścianie wieży głównej. Co do podziału funkcjonalnego wnętrz, to dolne kondygnacje miały przeznaczenie gospodarcze i magazynowe, mieszcząc m.in. kuchnię i piekarnię. Warto zaważyć, że nad pomieszczeniami pierwszego piętra skrzydła zachodniego i północnego (poniżej poziomu ganków obronnych) znajdowały się dwie kondygnacje spichrzowe. Nad skrzydłem południowym i wschodnim była natomiast tylko jedna, przez co sale pierwszego piętra były tam nieco wyższe. Skrzydło południowe uznawane jest za główne. Co do układu funkcjonalnego pomieszczeń piętra kasztelu są jednak rozbieżności w literaturze i temat ten wymaga dalszych badań ${ }^{54}$. W dwóch dużych salach skrzydła południowego lokalizowano więc refektarz letni (od wschodu) i zimowy (Schmid i Herrmann) lub refektarz i kapitularz ${ }^{55}$ (Clasen, Heise; Krantz-Domasłowska, Domasłowski). W jednej dużej sali zajmującej przestrzeń skrzydła wschodniego widzi się infirmerię (Heise; Herrmann, Schmid) lub ewentualnie dormitorium (Clasen). Te ostatnie najczęściej lokalizuje się jednak w skrzydle zachodnim, gdzie na piętrze była pierwotnie jedna wielka sala (Heise, Herrmann, Krantz-Domasłowska, Domasłowski; Schmid), przy czym zgodnie ze statutem z około 1400 r. kanonicy musieli mieć własne odrębne komory sypialne. Sala mogła zostać wówczas przedzielona drewnianymi ścianami, ale wskazuje się również możliwość, że komory te umieszczono na drugim piętrze. Magazynowy charakter tej kondygnacji każe jednak w to wątpić. W krótkim skrzydle północnym, mieszczącym kilka mniejszych pomieszczeń, Herrmann i Schmid lokalizują kapitularz. Ten ostatni ponadto kancelarię, mieszkanie proboszcza i kaplicę. Obecnie należy jednak tę koncepcję odrzucić. Kaplicy na zamku wysokim nie było, gdyż jej funkcję pełniła sąsiednia, połączona z kasztelem katedra (górny poziom chóru). Ponadto Heise, Krantz-Domasłowska

\footnotetext{
${ }^{54} \mathrm{Z}$ najnowszych publikacji na ten temat zob. Janusz TrupindA, „Zamek w Kwidzynie w czasach bł. Doroty z Mątowów na podstawie średniowiecznych źródeł historycznych", w: Studia z dziejów diecezji Pomezańskiej w 775. rocznice jej utworzenia. Materiaty z V. Sympozjum Dorotańskiego w Kwidzynie, red Justyna Liguz (Pelplin: Wydawnictwo „Bernardinum", 2020), s. 26-30.

${ }^{55}$ Fakt istnienia kapitularza w świetle najnowszej wiedzy budzi wątpliwości; zob. ibid., s. 28-29.
} 
A
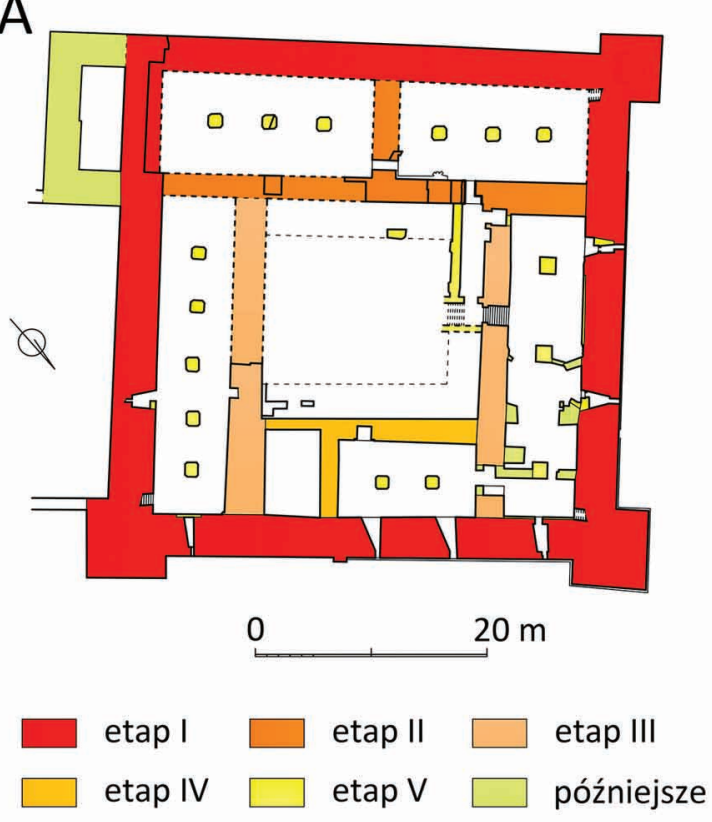

B

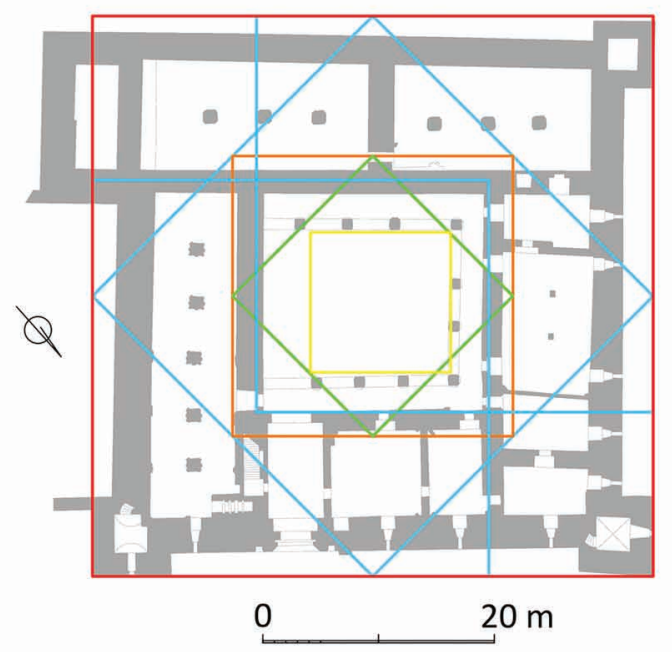

9. Kwidzyn, rzut zamku wysokiego (kasztelu): A - etapy budowy; B - rozrys ad quadratum. Rys. Bogusz Wasik

i Domasłowski doszukiwali się w tym skrzydle refektarza zimowego, który większość badaczy lokalizuje jednak w południowym ${ }^{56}$. W świetle ostatnich badań pomieszczenie nad bramą było pierwotnie podzielone na dwa, mieszcząc najpewniej kancelarię, którą ogrzewał piec akumulacyjny (zlokalizowany w piwnicy na wschód od bramy) ${ }^{57}$.

Co do techniki i kolejności budowy, to mimo badań architektonicznych i w niewielkim zakresie archeologicznych z przełomu lat 70-80. XX w. nie jest ona w pełni rozpoznana ${ }^{58}$. Obecnie do nowej analizy, poza starą dokumentacja, dostępne są przede wszystkim mury wnętrz piwnic ${ }^{59}$. Rozpoczynając jednak analizę od rzutu stwierdzić można, że projektując

\footnotetext{
${ }^{56}$ Clasen, Die mittelalterliche Kunst im Gebiete des Deutschordensstaates Preussen, s. 163; Mario Glauert, Das Domkapitel von Pomesanien (1284-1527) (Toruń: Wydawnictwo Naukowe UMK, 2003) s. 104-108 (Prussia sacra, 1); Johannes HeIse, Der Kreis Marienwerder östlich der Weichsel (Danzig: Kommissions-Verl. von Th. Bertling, 1898), s. 42-56 (Die Bau- und Kunstdenkmäler der Provinz Westpreußen, 11); Herrmann, „Die pomesanische Kapitelsburg und der Dom in Marienwerder", s. 235; Krantz, DomasŁowski, Katedra i zamek w Kwidzynie, s. 20-21; KRANTZ-DomaSŁOWSKA, „Der Dom und die Burg in Marienwerder (Kwidzyn)”, s. 218-220; Schmid, Die Domburg Marienwerder, s. 12. ${ }^{57} \mathrm{Na}$ funkcję kancelarii wskazuje m.in. obecność nisz z półkami; zob. Aleksander PIwEK, Kwidzyn-zamek kapituły (obecnie muzeum). Piętro - pomieszczenie nad przejazdem, Gdańsk 2017, s. 9-10, maszynopis w archiwum Muzeum Zamkowego w Malborku, sygn K/VI/1817; Juliusz RACZKOwsKI, ,Medieval murals recently uncovered in the chamber above the gate of the castle of the chapter of the diocese of Pomesania in Kwidzyn. Preliminary analysis: iconography, style, dating and functional role of the chamber", Ordines Militares Colloquia Torunensia Historica 22 (2017), s. 293-296.

${ }^{58} \mathrm{~W}$ ramach badań architektonicznych wydzielono główne fazy, jednak nie rozpoznano etapów realizacji pierwszej (głównej). Przeprowadzono wówczas też badania archeologiczne (1977-1979), jednak zarówno te, jak i wcześniejsze (1967) ze względu na brak kompleksowego charakteru i skromny zakres dokumentacji nie wnoszą konkretnej wiedzy na temat techniki budowy, przekształceń terenu związanych z inwestycją i charakteru prac ziemnych; zob. Anna CHRzANOwICZ, Badania architektoniczne, t. 1, Gdańsk 1977-1982, maszynopis w archiwum Muzeum Zamkowego w Malborku, sygn. K/VII/853; Antoni PawıowsKi, Wstępne wyniki badań archeologiczno-architektonicznych na zamku w Kwidzynie w latach 1977-1979, maszynopis w archiwum Muzeum Zamkowego w Malborku, sygn. K/VII/853; Iwona WoLANINSuŁDRZYŃSKa, Sprawozdanie z badań archeologicznych na zamku w Kwidzynie za rok 1977, Gdańsk 1977, maszynopis w archiwum Muzeum Zamkowego w Malborku, sygn. K/VII/853.

${ }^{59}$ Wyższe kondygnacje maja wnętrza otynkowane. Z tym samym utrudnieniem miała do czynienia Anna Chrzanowicz.
} 
gmach posłużono się nową miarą chełmińską. Ściany mają wysokość czterech prętów powyżej progu bramy (il. 8: A). Wyraźnie według tej miary wytyczono też wysoką niszę bramną, gdyż ma jeden pręt szerokości i znajduje się dwa pręty od wieży północnowschodniej. Analiza rzutu poziomego wykazuje ponadto, że do wyznaczenia proporcji kasztelu posłużono się najpewniej metodą geometryczną ad quadratum ${ }^{60}$. Wykorzystując wymiary kolejno wpisywanych w siebie kwadratów wyznaczono szerokości skrzydeł i dziedzińca w obrębie krużganka. Wysokości skrzydeł nie wyznaczono jednak tymi wymiarami, ale miara, jak wskazaliśmy, prętową - elewacja północna ma proporcje dwóch kwadratów o boku 4 prętów (il. 8: $\mathrm{B}, 9$ : B).

Zamek zbudowano „na surowym korzeniu” - na stoku opadającym ze wschodu (il. 10). Skarpowa lokalizacja ma pewną analogię w zamku krzyżackim w Kowalewie, choć tam kasztel zajmuje kulminację ${ }^{61}$. W efekcie znajdująca się wyżej katedra dostępna była przez wejście z poziomu pierwszego piętra kasztelu. Położenie takie musiało wymusić na budowniczych znaczne prace ziemne, choćby w celu wyrównania poziomu dziedzińca, których $\mathrm{z}$ powodu braku odpowiednich badań archeologiczno-architektonicznych nie jesteśmy w stanie przybliżyć. Wiadomo jednak, że w południowo-zachodniej części dziedzińca pierwotny stok wzgórza odkryto $1,75 \mathrm{~m}$ pod obecną powierzchnią ${ }^{62}$. W związku z tym piwnicę skrzydła zachodniego posadowiono bez wątpienia mniej więcej na pierwotnym poziomie gruntu, wykonując jedynie szerokoprzestrzenny rów w postaci półki w sto$\mathrm{ku}$. Podobne postępowanie stwierdzono ostatnio na zamku w Starogrodzie ${ }^{63}$. Ponadto z powodu braku badań nie wiadomo czy i ewentualnie w jakim zakresie po zewnętrznej stronie kasztelu usypano tarasy. $Z$ racji topografii wchodziłaby tu przede wszystkim w gre strona zachodnia. Co do etapów budowy kasztelu, to rozwarstwienie narożników piwnic utrudniają spływy żeber schodzące niemal do ziemi, jednak w kilku miejscach można węzły rozpoznać. Pomocna jest tu także analiza pomiarowa cegieł. Wydzielić można tu dwie zasadnicze grupy, różniące się przede wszystkim wymiarem wozówki. Tak więc w I etapie (il. 9: A) wzniesiono kurtynę obwodową, w której wykorzystano mniejsze cegły (ok. 80$90 \times 140-150 \times 295-320 \mathrm{~mm}$ ). Razem z nią zaczęto budować trzy narożne wieże, ale głównej wówczas nie przewidziano. Dostawiono ją wtórnie (wraz z korpusem katedry), kiedy kurtyna obwodowa była już wzniesiona, co wymusiło zamurowanie gotowych okien. Szew styku jest wyraźnie widoczny na ścianie południowej wieży ${ }^{64}$. Bez badań archeologicznych nie można przesądzić, czy planowano tu pierwotnie budowę czwartej, mniejszej wieży. Położenie wskazanej dylatacji względem dawnego narożnika zamku każe jednak w to watpić, gdyż przestrzeń na wieżę w formie pozostałych jest za mała. Ponadto, jak wskazano już w badaniach z lat 70-80. XX w., parterowe kondygnacje narożnych wież dostępne były przez wejścia prowadzące $z$ narożników piwnic ${ }^{65}$. Ściany skrzydeł dostawiono do obwodowej na styk, co widać zarówno w piwnicy zachodniej, jak i północnej.

\footnotetext{
${ }^{60}$ Zob. przypis 46.

${ }^{61}$ WASIK, Budownictwo zamkowe na ziemi chetmińskiej s. 103-105, 289-292; Bogusz WASIK, Marcin WIEWIÓRA, „Próba rekonstrukcji układu przestrzennego zamku wysokiego (domu konwentu) w Kowalewie Pomorskim na podstawie źródeł historycznych i najnowszych wyników badań archeologiczno-architektonicznych”, Wiadomości Konserwatorskie 45 (2016), s. 53-65.

62 PAWŁowsKi, Wstępne wyniki badań archeologiczno-architektonicznych na zamku w Kwidzynie, s. 2.

${ }^{63}$ Bogusz WAsık, „Zamki krzyżackie w okresie późnośredniowiecznym i nowożytnym. Analiza źródeł architektonicznych", w: Castra Terrae Culmensis. Na rubieży chrześcijańskiego świata, red. Marcin WiewióRa (Toruń: Wydawnictwo Naukowe UMK, 2020), t. 2, s. 42-96.

${ }^{64}$ ChrZAnowicz, Badania architektoniczne s. 144.

${ }^{65}$ Ibid., s. 35-36 (węzeł 32/p).
} 


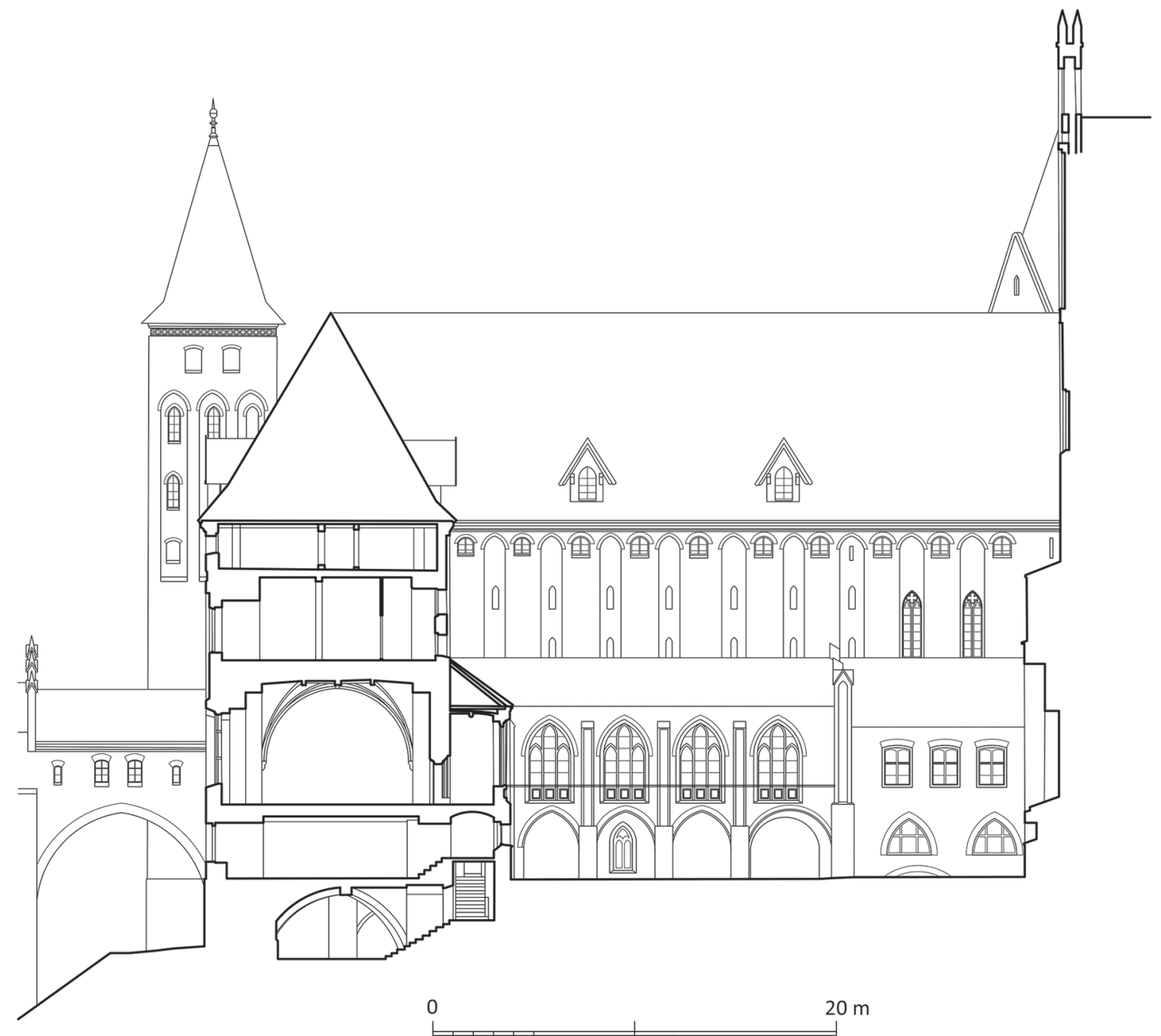

10. Kwidzyn, przekrój zachód-wschód (widok na pótnoc) przez kasztel (stan po przebudowach z XIX-XX w. Rys. Bogusz Wasik wedtug inwentaryzacji Ireny Jaroszewskiej-Bartoszewicz

W II etapie musiano wznieść skrzydło główne (południowe), przechodzące przez całą długość kasztelu. W III etapie (równolegle?) skrzydła zachodnie i wschodnie, które stanowiły pierwotnie pojedyncze długie pomieszczenia. Wykorzystano w nich cegły o podobnych formatach jak w kurtynie obwodowej. Jako ostatnie (etap IV) wstawiono skrzydło północne. Tu wykorzystano już, charakterystyczne dla dalszych etapów i naziemnych partii zamku, cegły mniejsze (ok. 80-90×140-150×290-300 mm). Na koniec inwestycji wskazać można wykonanie sklepień. Ponieważ nie odpowiadały one formą pierwotnym planom, wymusiło to w kilku miejscach całkowite (ściana północna piwnicy skrzydła wschodnieg ${ }^{66}$ ) lub częściowe (skrzydło wschodnie i zachodnie) zamurowanie niektórych okien. Pozostawiono przy tym czynne okno od wschodu, co wskazuje, że ten etap nastapił przed powstaniem katedry. Pod koniec musiano zbudować także krużganki z szyjami piwnicznymi. Zmieniono przy tym układ komunikacyjny piwnicy skrzydła zachodniego,

${ }^{66}$ Zob. A. Szmyt, Badania architektoniczno-archeologiczne w pótnocno-wschodniej partii zamku w Kwidzyniu, 1967, s. 6, maszynopis w archiwum Muzeum Zamkowego w Malborku, sygn. K/I/817, . 


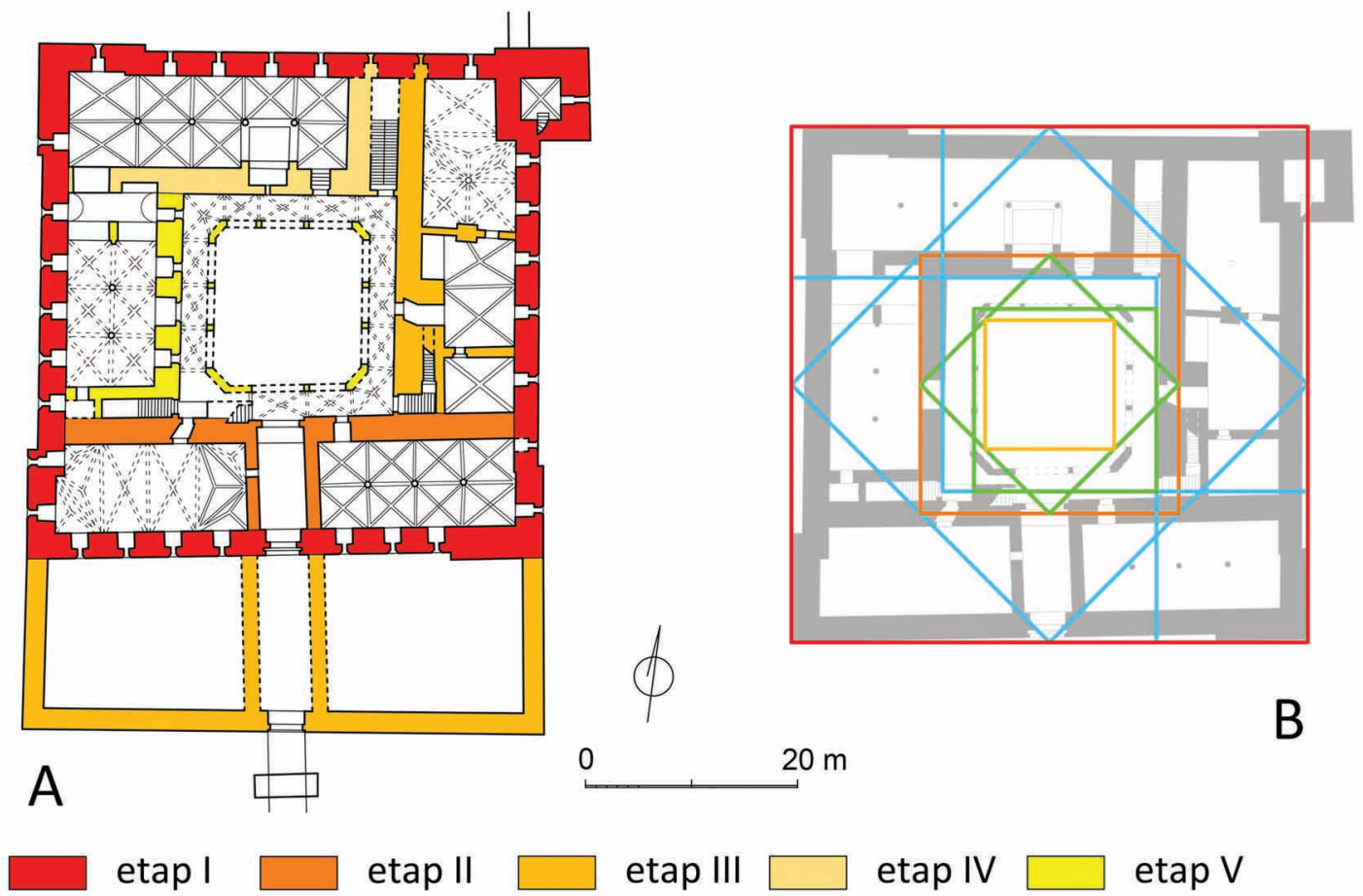

11. Lidzbark Warmiński, zamek wysoki (kasztel): A - rzut etapów budowy I fazy z ok. 1350-1373 r. Rys. Bogusz Wasik według badań Wojciecha Wółkowskiego; B - rzut I fazy zamku z wyznaczeniem proporcji metodq ad quadratum. Oprac. Bogusz Wasik

zamurowując pierwotne wejście w narożniku ${ }^{67}$. Następnie, w ciągu 2. połowy XIV w., zbudowano gdanisko i wieżę studzienną (il. 7), a także wieżę główną, realizując ją etapami zapewne do XV w. ${ }^{68}$ Podczas jej budowy zmieniano koncepcje (wydziela się cztery etapy), rezygnując m.in. na poziomie koron murów katedry i zamku z rozpoczętych wcześniej wysokich blend i kończąc je bez przesklepienia ${ }^{69}$.

Mniej więcej w tym samym czasie co zamki w Lubawie i Kwidzyniu powstała także kasztelowa siedziba biskupów sambijskich w Rybakach. Skromny stan wiedzy na jej temat nie pozwala jednak na głębszą analizę ${ }^{70}$. Jednym z najlepiej zachowanych gotyckich zamków w Polsce, a zarazem najmłodszym omawianym obiektem, jest bez wątpienia rezydencja biskupów warmińskich w Lidzbarku Warmińskim. Przeprowadzone w ostatnich latach badania uzupełniły znacząco wiedzę o obiekcie, zmieniając też dawne interpretacje odnośnie do przekształceń budowlanych zamku ${ }^{71}$. Na podstawie cech formalnych można

\footnotetext{
${ }^{67}$ ChrZanowicz, Badania architektoniczne, s. 38, 41 (węzeł 39/p i 50/p).

${ }^{68}$ Herrmann, Mittelalterliche Architektur im Preussenland, s. 593; Krantz-DomasŁowsKa, „Der Dom und die Burg in Marienwerder (Kwidzyn)", s. 216.

${ }^{69}$ Hanna DomańsKa, Zamek kapituly pomezańskiej w Kwidzynie. Dokumentacja naukowo-historyczna wykonana na zlecenie Wojewódzkiego Konserwatora Zabytków w Gdańsku, Gdańsk 1968-1969, s. 62-66, maszynopis w archiwum Muzeum Zamkowego w Malborku, sygn. nr K/VII/852; HeISE, Der Kreis Marienwerder östlich der Weichsel, s. 70-71. ${ }^{70}$ Zob. JarZeBowski, Die Residenzen der Preussischen Bischöfe bis 1525, s. 140-154.

${ }^{71}$ M.in. Radosław HeRMAn, ,Nowe spojrzenie na przedzamcze w Lidzbarku Warmińskim. Wstępne wyniki badań archeologicznych”, w: Dni dziedzictwa Warmii. ,,Skarby Warmii” (Lidzbark Warmiński: Starostwo Powiatowe, 2009), s. 6390 (Dziedzictwo Warmii); Arkadiusz KoPERKIEWICZ, „Badania archeologiczne na południowym tarasie zamku biskupów w Lidzbarku Warmińskim”, Gdańskie Studia Archeologiczne 5 (2015), s. 113-174; Magdalena SKARŻYŃSKA-WaWRYKIEWICZ, Leszek WAWRYKIEWICZ, „Rola badań architektonicznych prowadzonych w zabytkach na przykładzie adaptacji przedzamcza
} 


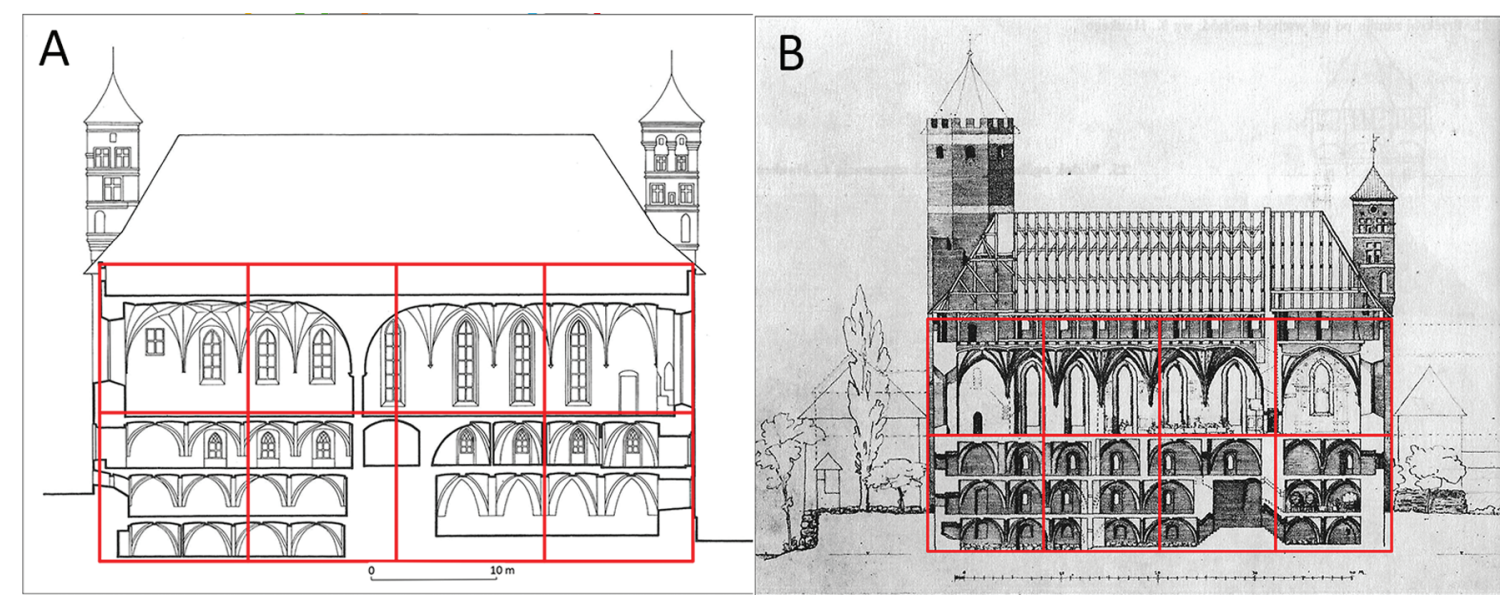

12. Lidzbark Warmiński, przekroje skrzydet zamku wysokiego (kasztelu) z zaznaczeniem proporcji przy pomocy kwadratów:

A - skrzydło główne (poludniowe); B - skrzydło wschodnie.

Oprac. Bogusz Wasik wedlug Architektura gotycka w Polsce, Warszawa 1995, t. 2, s. 447 i Conrada Steinbrechta
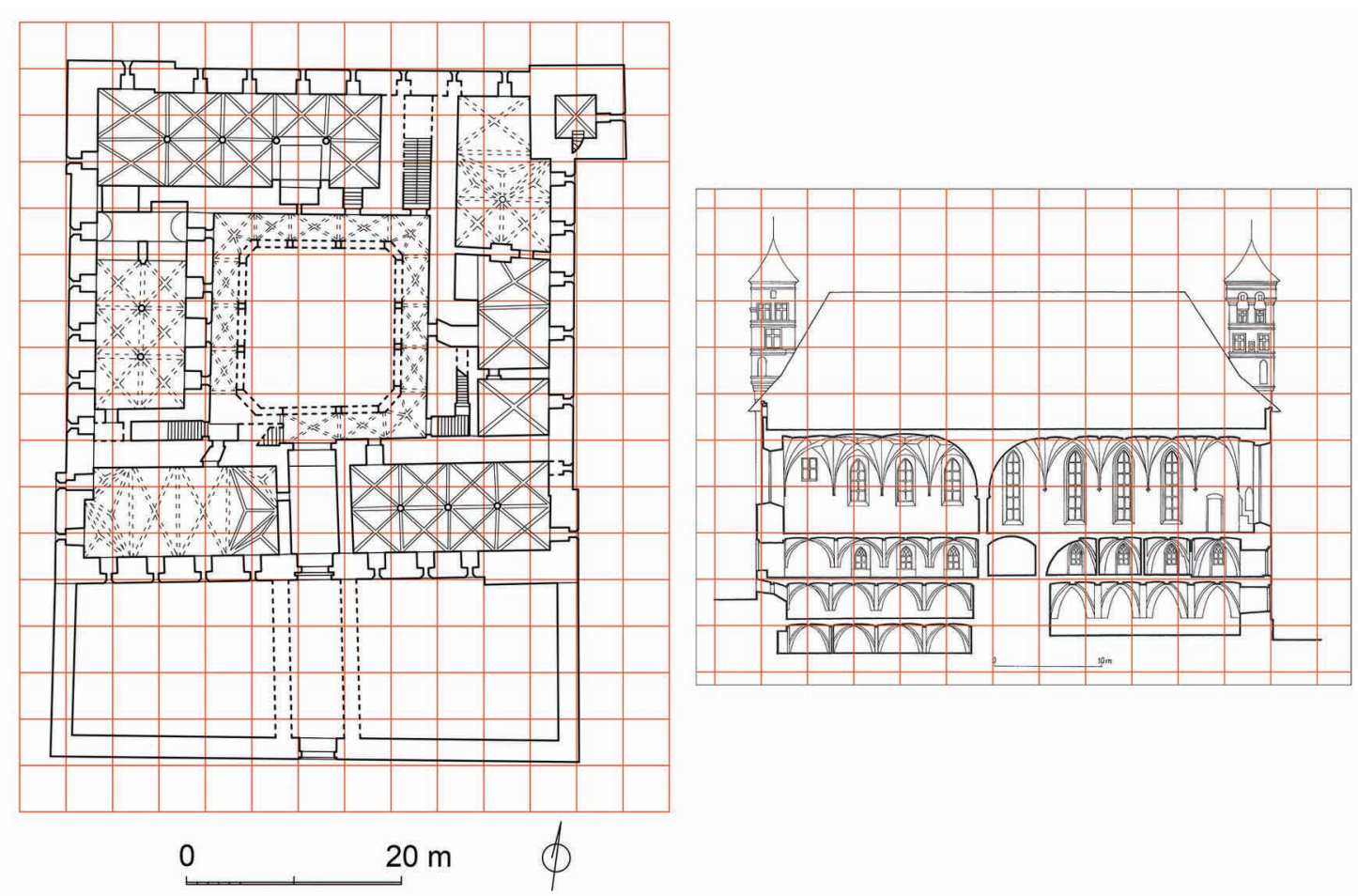

13. Lidzbark Warmiński, zamek wysoki (kasztel) na siatce o module 1 pręta nowej miary chetmińskiej: A - rzut I fazy zamku; B - przekrój skrzydta głównego (potudniowego) po przebudowach z XV-XVI w. Oprac. Bogusz Wasik wedtug Wojciecha Wótkowskiego (rzut) $i$ Architektura gotycka w Polsce, Warszawa 1995, t. 2, s. 447 (przekrój) 
go łączyć z późnymi krzyżackimi kasztelami, cechującymi się upraszczaną architektura, choć wyróżnia go obecność wieży ${ }^{72}$.

Zamek składał się z głównego członu - kasztelu i przedzamcza (od południa). Czas inwestycji jest dobrze naświetlony źródłami pisanymi. Wynika z nich, że zasadnicze prace przy kasztelu wykonano w latach 1350-1373 (faza I) ${ }^{73}$. Zamek wysoki wzniesiono na planie zbliżonym do kwadratu $(47,6 \times 49,2 \mathrm{~m})$ i osłonięto parchamem jedynie od strony przedzamcza i wjazdu (il. 11: A). Narożnik północno-wschodni zajęła wysunięta oktogonalna wieża główna na czworobocznej podstawie. Smukła i scalona ze skrzydłami wieża nie była jednak, jak w Wąbrzeźnie, typowym bergfridem, jej walory obronne były ograniczone, a znaczenia w dużej mierze należy doszukiwać się w sferze semantyki władzy ${ }^{74}$. Narożne wieżyczki kasztelu dodano dopiero po pożarze z 1442 r., zastępując zapewne szczyty, a następnie podwyższono dwukrotnie w XVI w. ${ }^{75}$ Komunikację poziomą zapewniały dookolne krużganki, przy czym te w obecnym kształcie powstały dopiero $\mathrm{w} X \mathrm{X} \mathrm{w}{ }^{76}$, pionową zaś reprezentacyjne schody od wschodu i kręcone w ścianach skrzydła południowego oraz wschodniego ${ }^{77}$. Wertykalny układ funkcjonalny określić można jako standardowy, podobny do opisanych wcześniej. Wyjątkowe jest jednak to, że wszystkie skrzydła miały dwa poziomy piwnic ${ }^{78}$ (il. 12). W przyziemiu od wschodu mieściły się magazyny, od północy browar, a od zachodu kuchnia i najpewniej szkoła ${ }^{79}$. Układ funkcjonalny piętra, przed pożarem z 1442 r. i późniejszymi przekształceniami rekonstruuje się następująco: w skrzydle południowym od wschodu znajdowała się kaplica, natomiast od zachodu refektarz (oba wnętrza rozdzielało pierwotnie wąskie pomieszczenie nad bramą); skrzydło wschodnie mieściło zakrystię i apartamenty biskupa ${ }^{80}$; w skrzydle zachodnim znajdowała się sala reprezentacyjna (audiencyjna?) i przejście do gdaniska; pierwotne funkcje pomieszczeń skrzydła północnego, z których wschodnie było niższe i przechodził przez nie komin kuchenny, nie są jasne. Wyżej mieściły się spichrze i ganki obronne ${ }^{81}$.

Brak przesłanek, że zamek zrealizowano w miejscu starszej warowni drewniano-ziemnej z XIII w., choć odkryto wczesnośredniowieczną warstwę, wskazującą na obecność

w Lidzbarku Warmińskim”, Wiadomości Konserwatorskie 30 (2001), s. 7-42; Wojciech WóŁKowski, Zamek biskupów warmińskich w Lidzbarku Warmińskim - dzieje budowlane i problemy konserwatorskie (Olsztyn: Muzeum Warmii i Mazur, 2016).

${ }^{72}$ Clasen, Die mittelalterliche Kunst im Gebiete des Deutschordensstaates Preussen, s. 168; zob. też: Torbus, Zamki konwentualne państwa krzyżackiego, s. 238-243.

${ }^{73}$ JarZeBowski, Die Residenzen der Preussischen Bischöfe bis 1525, s. 91; WóŁKOwSKI, Zamek biskupów warmińskich w Lidzbarku Warmińskim, s. 31-47.

${ }^{74}$ Izabela BRzostowsKA, „Die Haupttürme der Burgen in Heilsberg und Rössel - zwei gegensätzliche Werke in der Wehrarchitektur Ermlands", w: Echte Wehrhaftigkeit oder martialische Wirkung: Zur praktischen Funktion und zum Symbolcharakter von Wehrelementen profaner und sakraler Bauten im Deutschordensland Preußen und im Ostseeraum, red. Gerhard Eimer, Ernst GierLich (Köln: Wissenschaft und Politik, 2000), s. 104-105 (Kunsthistorische Arbeiten der Kulturstiftung der deutschen Vertriebenen, 3).

75 JaRZEBOwski, Die Residenzen der Preussischen Bischöfe bis 1525, s. 98; WóŁKowsKi, Zamek biskupów warmińskich w Lidzbarku Warmińskim, s. 49, 74, 81.

${ }^{76}$ Wółkowski, Zamek biskupów warmińnkich w Lidzbarku Warmińskim, s. 49.

${ }^{77}$ Ibid., s. 41.

78 Później, po pożarze z 1442 r. zagruzowano dolny, zachodni poziom piwnic skrzydła południowego; WóŁKOwSKI, Zamek biskupów warmińskich w Lidzbarku Warmińskim, s. 48.

79 JARZEBowski, Die Residenzen der Preussischen Bischöfe bis 1525, s. 107; WóŁKOwsKI, Zamek biskupów warmińskich w Lidzbarku Warmińskim, s. 40.

${ }^{80}$ Wielki Refektarz był pierwotnie podzielony na mniejsze wnętrza.

${ }^{81}$ WóŁKOwsKI, Zamek biskupów warmińskich w Lidzbarku Warmińskim, s. 37-40. 
osadnictwa ${ }^{82}$. W świetle ostatnich badań był on od początku planowany jako czteroskrzydłowy kasztel. Analiza rzutu wskazuje, że także w Lidzbarku proporcje budowli wyznaczono metodą ad quadratum ${ }^{83}$ (il. 11: B). Proporcje wysokości (od poziomu najniższej piwnicy) do szerokości skrzydeł wynoszą 1:2 (i1. 12). Budowniczowie wykorzystywali ponadto nową miarę chełmińską - dolne kondygnacje mają ewidentnie po jednym pręcie wysokości (il. 13). Inwestycję, podobnie jak w poprzednio opisanych zamkach, prowadzono etapami, wykonując we wznoszonych ścianach strzępia i opory wykorzystywane przy dalszych pracach (il. 11: A). Także tu w toku budowy wprowadzano korekty do pierwotnego planu, czego efektem było np. zamurowywanie niektórych otworów okiennych. W etapie I zaczęto wznosić mur obwodowy (wraz z wieżą). Następnie przystąpiono do murowania piwnic skrzydeł i ich przesklepiania. Skrzydła budowano dostawiając je do kurtyny, w kolejności: południowe (etap II), nieco później lub równolegle z poprzednim wschodnie (etap III), a następnie północne (etap IV) i na końcu zachodnie (etap V). Prawdopodobnie równolegle z budową skrzydeł wykonano fundamenty (pierwotnych) krużganków. Od początku planowano też (wykonując strzępia) parcham południowy z szyją bramna, ale dostawiono go w którymś z późniejszych etapów ${ }^{84}$. Mury szyi zbudowano na fundamentach arkadowych ${ }^{85}$. Wznosząc mury zamku wykonano też znaczne prace ziemne, podnosząc poziom dziedzińca o około trzy metry. Wykonując nasyp przykryto też wykonane wcześniej fundamenty krużganka ${ }^{86}$. Parchamu początkowo nie wypełniono ziemią. Stał on tak na tyle długo, że na poziomie budowlanym wytworzyła się warstwa kulturowa. Dopiero pod koniec pierwszej fazy budowy kasztelu wypełniono go nasypem, podnosząc jego poziom o 2,5-3 $\mathrm{m}^{87}$. Fakt wytworzenia przedtem warstwy użytkowej wskazuje, że sam mur zbudowano w jednym z pierwszych etapów inwestycji.

Z powyższej charakterystyki wynika, że podobieństwa między kasztelami hierarchii kościelnej a krzyżackimi nie kończą się jedynie na ogólnych cechach formy, dotyczą bowiem też techniki budowy. Jedynie zamek w Wąbrzeźnie w tej kwestii odbiega. Jest to najstarszy biskupi zamek tego typu i cechuje go bardziej swobodne podejście do recepcji wzoru kasztelu konwentualnego. Mimo cech zbieżnych z wczesnymi kasztelami ziemi chełmińskiej, jak nieduży rozmiar, prosta forma i nieregularny obwód zewnętrzny, widać tu też wiele nietypowych cech, takich jak obecność tylko trzech skrzydeł, z których tylko jedno wyróżnia się pełnym programem architektonicznym z gankiem i podpiwniczeniem, czy usytuowanie wieży na osi kurtyny i bezpośrednie komunikacyjne jej połączenie ze skrzydłem. Te odmienności ujawniają się także w technice budowlanej, gdyż nie wykonano typowych dla domów konwentów prac nasypowych w celu podniesienia i wyrównania dziedzińca oraz parchamu. W efekcie zastosowano inny, bardziej tradycyjny sposób posadowienia piwnicy, wymagający wykopania głębszego szerokoprzestrzennego rowu. W krzyżackich kasztelach posadowiano ją bowiem standardowo mniej więcej na poziomie pierwotnego gruntu lub delikatnie zagłębiając - wyrównując teren, murowano na jej poziomie ściany z wolnej ręki, po czym teren wokoło podnoszono nasypami, przysypując

\footnotetext{
${ }^{82}$ KoPERKIEWICZ, „Badania archeologiczne na południowym tarasie zamku biskupów w Lidzbarku Warmińskim”, s. 165.

${ }^{83}$ WASIK, „Techniki budowy zamków w typie kasztelu”, s. 51.

${ }^{84}$ WóŁKOWSKI, Zamek biskupów warmińskich w Lidzbarku Warmińskim, s. 34-35.

${ }^{85}$ Koperkiewicz, „Badania archeologiczne na południowym tarasie zamku biskupów w Lidzbarku Warmińskim”, s. 157158.

${ }^{86}$ WóŁKOwsKI, Zamek biskupów warmińskich w Lidzbarku Warmińskim, s. 35, przypis 31.

${ }^{87}$ KoPERKIEWICZ, „Badania archeologiczne na południowym tarasie zamku biskupów w Lidzbarku Warmińskim”, s. 161166.
} 


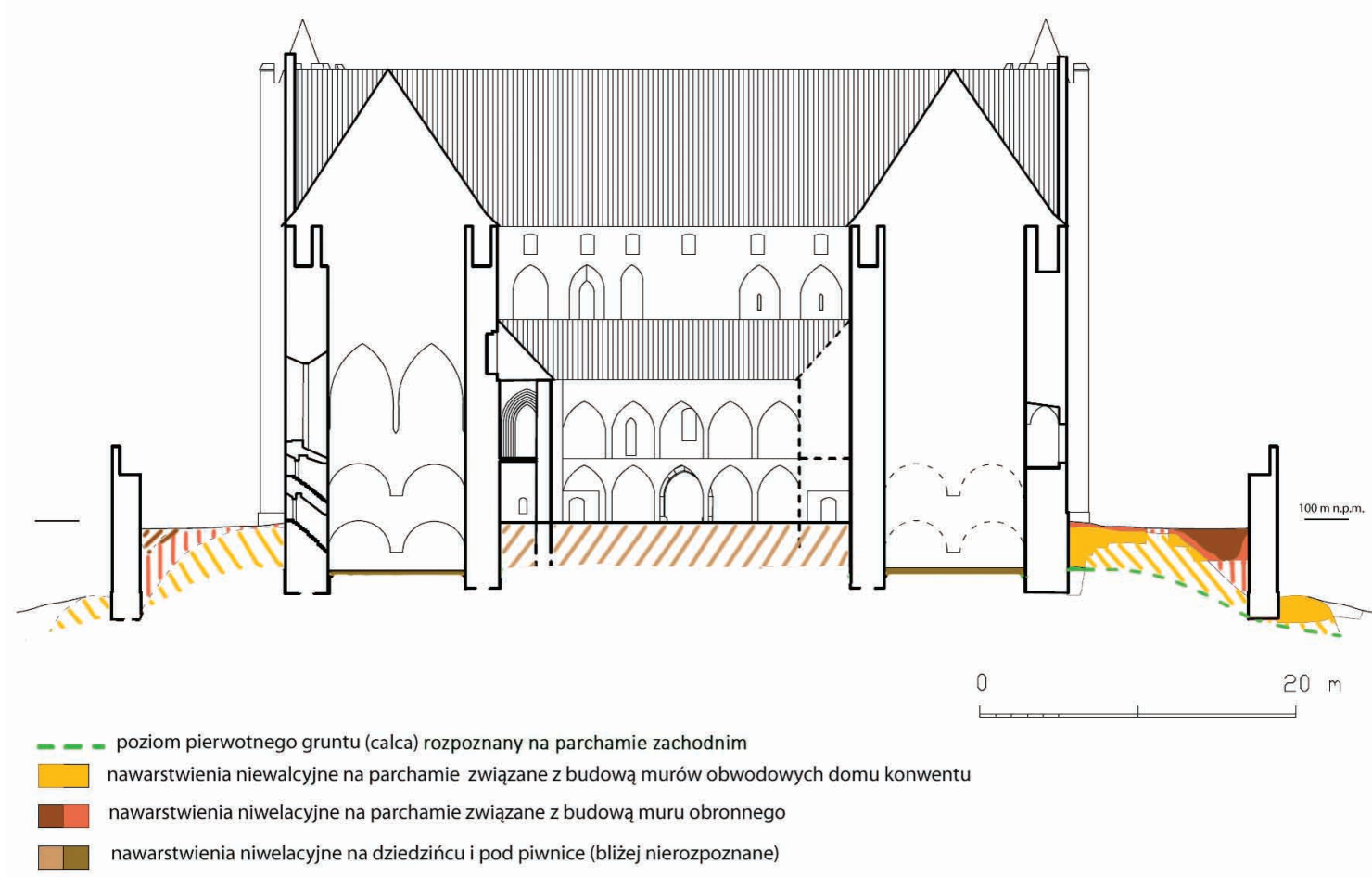

14. Radzyń Chetmiński, przekrój przez dom konwentu. Przykład zakresu prac ziemnych (nasypowych) w tzw. klasycznym zamku konwentualnym. Oprac. Bogusz Wasik

mury i zagłębiając piwnicę $w$ gruncie ${ }^{88}$. Biorąc ponadto pod uwagę wskazaną wcześniej niską jakość detalu, wnioskować można, że biskupi nie zatrudnili budowniczych realizujących zamki krzyżackie, ale zapewne tańszy warsztat, któremu zlecili wykonanie założenia na wzór krzyżackich. Co ciekawe, badania wykazały, że przy późniejszej budowie przedzamcza zastosowano już bardziej zaawansowane techniki, co wskazuje na zmianę warsztatu na bardziej doświadczony ${ }^{89}$. Słabsza jakość warsztatu mogła wynikać z możliwości finansowych biskupów chełmińskich w początku XIV w., jak i z faktu, że wkrótce po rozpoczęciu inwestycji nastapiła niemal dekada wakatu na tym stanowisku. Kolejne biskupie i kapitulne kasztele (Lubawa, Kwidzyn, Lidzbark Warmiński) mają już cechy techniki budowy analogiczne do zamków krzyżackich tego typu ${ }^{90}$. Można więc tu dostrzec stosowanie metod projektowania opartych ad quadratum, ten sam powtarzalny system etapowania budowy, w którym w pierwszej kolejności wznoszono kurtynę obwodową, do której dostawiano sukcesywnie skrzydła, poczynając od głównego, a także nieustępujący dużym krzyżackim inwestycjom znaczny zakres prac ziemnych - nasypowych, obejmujących przemieszczanie co najmniej kilku tysięcy metrów sześciennych ziemi (il. 14). Jednak również w tych zamkach można dostrzec pewne niedoskonałości warsztatowe. Kasztele w Kwidzynie i Lubawie cechują się bowiem pewną niestaranno-

\footnotetext{
${ }^{88}$ WASIK, Budownictwo zamkowe na ziemi chetmińskiej s. 70-71; ID., „Techniki budowy zamków w typie kasztelu”, s. 39; ID., „Zamek w Świeciu”, s. 228.

${ }^{89}$ WASIK, Budownictwo zamkowe na ziemi chetmińskiej s. 122-126 ; ID., „Próba rekonstrukcji etapów budowy i układu przestrzennego zamku", s. 211-212.

90 Zob. WASIK, Budownictwo zamkowe na ziemi chetmińskiej s. 321-322; ID., „Techniki budowy zamków w typie kasztelu".
} 
15. Działdowo, przekrój przez główne skrzydto zamku: na piętrze kaplica i refektarz. Repr.wg Conrad Steinbrecht, Die Ordensburgen der Hochmeisterzeit, Berlin 1920, il. 119

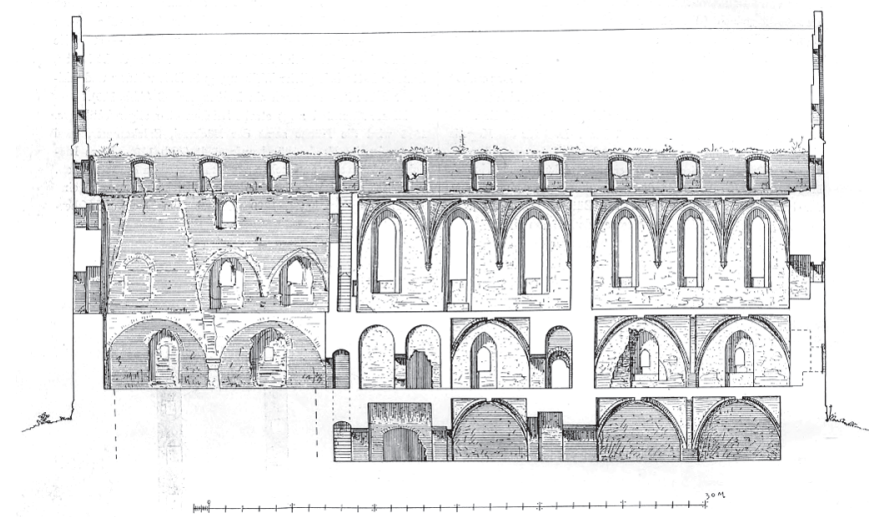

ścią w wytyczaniu planu - odchyłami linii kurtyn od kątów prostych, co w takim stopniu nie występuje w krzyżackich założeniach z tego czasu (Radzyń Chełmiński, Brodnica). Ponadto cegły zastosowane w Kwidzynie (zwłaszcza w piwnicach) cechuje słaba jakość, najprawdopodobniej na skutek złego przygotowania ciasta glinianego przed wypałem. Być może także na tym zaważyły mniejsze możliwości finansowe inwestorów, które również uniemożliwiły zbudowanie w Lubawie skrzydła zachodniego zgodnie z planem.

W tym miejscu należy powrócić do pytania o ewentualne zapóźnienie stylowe ${ }^{91}$. Sąd taki należy odrzucić, gdyż budowle te realizowano według tych samych wzorców stylistycznych, co budowane w tym samym czasie krzyżackie domy konwentów. Tak więc Wąbrzeźno ma wiele cech wczesnych kaszteli ziemi chełmińskiej, których ostatnie przykłady (Golub) powstają w 1. ćwierci XIV w., zamki w Lubawie i Kwidzynie mają cechy budowanych w tym samym czasie (ok. 1310-1350) tzw. klasycznych kaszteli konwentualnych (duże gabaryty, konsekwentne stosowanie ryzalitowych, czworobocznych wież ze ściętym narożnikiem od wnętrza zamku, jak w Radzyniu Chełmińskim i Brodnicy), wielki zakres prac ziemnych, nadanie większej lekkości architekturze, dzięki zastosowaniu artykulacji blendami w Kwidzynie, co daje podobny efekt, jak rozczłonkowanie elewacji wysokimi oknami w Radzyniu Chełmińskim, natomiast zamek w Lidzbarku Warmińskim (pozbawiony pierwotnie wieżyczek narożnych) wpasowuje się w zredukowane formy wznoszonych w tym samym czasie (ok. 1350-1410) schyłkowych kaszteli krzyżackich. Hierarchowie kościelni korzystali więc wyraźnie z jak najbardziej aktualnych prądów w architekturze. Ze względu na kontakty i obracanie się w jednym środowisku intelektualnym nie bez znaczenia jest zapewne fakt, że trzy z czterech kapituł należały do zakonu. Symptomatyczne wydaje się tu przy tym to, że kasztelowa siedziba biskupów warmińskich, a więc jedynej diecezji, która nie została w takim stopniu podporządkowana Krzyżakom, powstał wyraźnie później. Podkreśla się znaczenie związku kapituł z zakonem dla wyboru formy, np. w Kwidzynie.

Tak więc wybór kasztelu na siedzibę kapituły miał uwypuklać jej związek z krzyżacką korporacja, ale jednocześnie przez scalenie go z katedrą wykreowano zupełnie nowy twór i środek wyrazu, wskazujący na jedność kapituły i Kościoła. Nastąpiła tam ,sakralizacja zamku", ale dominacja bryły katedry sprawia, że środek ciężkości i akcent przesunięty jest na instytucję Kościoła ${ }^{92}$. Poza zwykłym przejęciem wzorca widać tu więc bardzo indywidualne podejście, łączące się także z semantyką władzy. Potężna bryła zespołu zamkowo-katedralnego dominowała nad niewielkim miastem i nadal góruje nad

\footnotetext{
${ }^{91}$ Clasen, Die mittelalterliche Kunst im Gebiete des Deutschordensstaates Preussen, s. 160.

92 Krantz-DomasŁowsKa, „Der Dom und die Burg in Marienwerder (Kwidzyn)”, s. 220.
} 
doliną Wisły, będąc widoczną z odległości wielu kilometrów. Przekaz ten jest jasny i podkreśla władzę kapituły na terenie jej władztwa. Ta symbolika nie była oczywiście też obca Krzyżakom. Monumentalne bryły ich zamków odgrywały ważną rolę w propagandzie władzy zakonu, podkreślając, także dzięki powtarzalności formy, status społeczny i jednorodność warstwy rządzącej władztwem w Prusach ${ }^{93}$. Krzyżacy nie stworzyli w tym celu całkiem nowej formy, ale sięgnęli po typ zamku o ugruntowanej w XIII w. semantyce z konotacjami z silną władzą centralną ${ }^{94}$. Właśnie poszukiwanie nowych form podkreślających semantykę władzy, a zarazem odpowiedniej scenerii dla życia dworskiego elit feudalnych dominiów, zaowocowało indywidualnymi cechami omawianych zamków kościelnych. Co ciekawe, kiedy zdominowany przez rycerzy-zakonników zakon krzyżacki stawiał na podkreślenie roli korporacji jako niewzruszonych milites christi, czemu służyć miały monolityczne zamki z wyraźnymi akcentami militarnymi w postaci potężnych bergfridów ${ }^{95}$, to autokreacja hierarchii kościelnej, stanowiącej de facto władzę feudalną w diecezjalnych dominiach, czerpiąc z podobnego zasobu form symbolicznych położyła ewidentnie większy akcent na dworski charakter rezydencji. Biskupi byli bowiem, niezależnie od pozycji w hierarchii kościelnej, władcami feudalnymi i terytorialnymi w swoich włościach ${ }^{96}$. Zwraca więc uwagę fakt, że żaden z omawianych zamków nie miał wieży głównej w typie bergfridu. Co prawda w zamku lubawskim w ogóle głównej wieży nie było, ale w innych przypadkach sięgnięto jednak po nią jako budowlę o ugruntowanej feudalnej symbolice władzy. Na fakt, że zdawano sobie sprawę z tej starej semantyki i że nie była ona bez znaczenia, wskazuje budowa wieży w Lidzbarku Warmińskim w okresie, kiedy Krzyżacy już ich na swoich kasztelach nie realizowali. Ograniczone walory obronne tych wież świadczą, że właśnie w sferze znaczeniowej należy się doszukiwać istotnego elementu ich funkcji. Jednym z przejawów realizacji władzy terytorialnej biskupów było sprawowane na zamkach sądownictwo ${ }^{97}$. W tym kontekście należy przytoczyć ciekawą informację z 1412 r. o sądzie biskupa chełmińskiego nad Marcinem z Golubia w celu pozbawienia tego ostatniego godności kościelnych. Odbył się on bowiem na moście prowadzącym do zamku wysokiego ${ }^{98}$. Sceneria została tu bez watpienia przemyślnie dobrana i właśnie ważne w niej miejsce zajmowała górująca za plecami biskupa wieża zamku (il. 2: A). W Kwidzynie wieża główna scalona w jedność z dzwonnica kościelną podkreślała ponadto, wskazany wyżej, program ideowy łączący zamek z katedra.

Ze względu na odmienność potrzeb hierarchii kościelnej modyfikacji wymagał układ funkcjonalny wnętrz względem kaszteli krzyżackich. Były to modyfikacje oczywiste, wynikające choćby w przypadku zamków biskupich z faktu, że ze względu na brak ,zbiorowego" - korporacyjnego właściciela, zbędne były dormitoria, zastąpione apartamentami biskupa ${ }^{99}$. Wynikało to z oczywistych względów funkcjonalnych - na zamku kapituły

\footnotetext{
${ }^{93}$ Marian Kutzner, „Propaganda władzy w sztuce Zakonu Niemieckiego w Prusach”, w: Sztuka w kręgu Zakonu Krzyżackiego w Prusach i Inflantach, red. Marcin WoźNIAK (Toruń: Uniwersytet Mikołaja Kopernika, Stowarzyszenie Historyków Sztuki. Oddział Toruń, 1995), s. 45-48 (Studia Borussico-Baltica Toruniensia Historiae Artium, 2).

94 Szczęsny SkibIŃSKI, „Jeszcze raz w kwestii genezy regularnego zamku krzyżackiego”, w: Sztuka Prus XIII-XVIII wieku, red. Marcin WoźNıAK (Toruń: Uniwersytet Mikołaja Kopernika, Stowarzyszenie Historyków Sztuki. Oddział Torun, 1994), s. 27-38 (Studia Borussico-Baltica Toruniensia Historiae Artium, 1).

95 Szczególną formę otrzymały w tym celu prawdopodobnie wieże w Brodnicy i zapewne w Gdańsku; zob. ToRBus, Zamki konwentualne państwa krzyżackiego, s. 197-198, 230.

96 JARZEBowski, Die Residenzen der Preussischen Bischöfe bis 1525, s. 193-196.

97 Ibid., s. 297.

98 JóźWIAK, TRUPINDA, „Zamek biskupów chełmińskich w Wąbrzeźnie”, s. 55.

${ }^{99}$ Herrmann, „Mittelalterliche Bischofs- und Kapitelsburgen im Preußenland”, s. 157.
} 
w Kwidzynie dormitoria zastosowano. Czy więc różnice te były aż tak znaczące? Podział wertykalny, z umieszczeniem głównych pomieszczeń na pierwszym piętrze, ponad gospodarczym przyziemiem (obejmującym m.in. kuchnię) występuje zarówno na zamkach krzyżackich, jak i hierarchii duchownej i de facto można uznać raczej za standardowy dla architektury zamkowej i rezydencjonalnej. Jeżeli chodzi o funkcje pomieszczeń, to poza wskazanymi sypialnymi we wszystkich zamkach, niezależnie od przynależności, wyróżniało się skrzydło główne, mieszczące dużą kaplicę i sąsiadujący z nią refektarz ogrzewany piecem akumulacyjnym. Nie widać tu więc wyraźnej różnicy w stosunku do zamków krzyżackich. Nie zakłóca tego obrazu brak kapitularzy na zamkach biskupich, gdyż w świetle ostatnich badań wyodrębnionych wnętrz o tej funkcji nie było też na zamkach konwentualnych ${ }^{100}$.

Są tu jednak także rozbieżności. W Kwidzynie, z racji sąsiedztwa katedry, w skrzydle głównym nie było kaplicy, natomiast w Wąbrzeźnie i Lubawie główne skrzydło było podzielone na trzy równe lokalności (il. 2: C, 5). Ten podział odbiega więc od najczęściej stosowanego w zamkach konwentualnych, gdzie środkowe wnętrze (między kaplicą i refektarzem) było wąskie ${ }^{101}$. Jednak także w zamkach krzyżackich można spotkać odstępstwa od takiego układu, jak w Brodnicy ${ }^{102}$. W Lidzbarku Warmińskim początkowo zastosowano ten standardowy podział wnętrz skrzydła głównego. W przypadku tego zamku Christofer Herrmann zwrócił uwagę, podobnie jak wcześniej Clasen odnośnie do Kwidzyna, że sale, w tym kaplica, nie różnią się wielkością i ich funkcja jest trudna do odgadnięcia po formie ${ }^{103}$ (il. 13: B). Trudno jednak stwierdzić, na ile było to regułą, biorąc pod uwagę, że tylko zamek w Lidzbarku zachował się w całości. W Kwidzynie pogląd o równości sal nie jest bowiem zgodny z prawdą, gdyż, jak wskazano, te w skrzydle głównym były wyższe, akcentując jego znaczenie. Zresztą także na niektórych zamkach krzyżackich wznoszonych po połowie XIV w. kaplicy nie wyróżniano wysokością od sąsiednich sal, jak np. w Działdowie (il. 15) i Nidzicy ${ }^{104}$. Chociaż wskazywane różnice nie były tak głębokie dzięki zastosowaniu finezyjnych rozwiązań architektonicznych i wyrafinowanemu podejściu, architektura kościelnych hierarchów nabierała bardziej dworskiego charakteru niż krzyżacka. To dostosowanie do semantyki i stylu życia dworskiego, charakterystycznego dla feudalnych elit XIV-wiecznej Europy, jest szczególnie dostrzegalne w najlepiej zachowanym zamku w Lidzbarku Warmińskim ${ }^{105}$. Uzyskano to m.in. kreując drogę ceremonialną, prowadzącą przez zaakcentowaną bramę zamkową i reprezentacyjne schody na piano nobile. Wymowę całości uzupełniał wystrój malarski, niosący treści podkreślające niezależność władzy biskupów ${ }^{106}$. Elementy takiego dworskiego

\footnotetext{
${ }^{100}$ Sławomir JóźwiAK, Janusz TRUPINDA, Krzyżackie zamki komturskie w Prusach. Topografia i układ przestrzenny na podstawie średniowiecznych źródel pisanych (Toruń: Wydawnictwo Naukowe UMK, 2012), s. 294-343.

101 Torbus, Zamki konwentualne państwa krzyżackiego, s. 357.

102 WASIK, Budownictwo zamkowe na ziemi chetmińskiej, s. 299-300.

103 Clasen, Die mittelalterliche Kunst im Gebiete des Deutschordensstaates Preussen, s. 164; Christofer Herrmann, „Heilsberg im Kontext des ermländischen Burgenbaus”, w: Burgen kirchlicher Bauherren, red. G. Ulrich Grossman, Hans HäFfner (München-Berlin: Deutscher Kunstverlag, 2001), s. 223 (Forschungen zu Burgen und Schlössern, 6).

${ }^{104}$ Zob. Conrad SteinBrecht, Die Ordensburgen der Hochmeisterzeit in Preussen. Bau-aufnahmen und Baugeschichtliche Würdigung der noch Vorhandenen Burgen und Bedeutenderen Burg-Reste des Ordens in Preussen aus der zeit von 1310 bis zum ende der Ordens-Herrschaft (Berlin: Julius Springer, 1920), il. 119, 132 (Die Baukunst des Deutschen Ritterordens in Preussen, 4).

${ }^{105}$ Carl H. Clasen określił wręcz architekturę zamku w Lidzbarku Warmińskim jako pałacową; zob. Clasen, Die mittelalterliche Kunst im Gebiete des Deutschordensstaates Preussen, s. 168.

${ }^{106}$ PiLeCKA, „Residenz der ermländischen Bischöfe in Heilsberg (Lidzbark Warmiński)”, s. 268-275.
} 
charakteru architektury można dostrzec jednak także w pozostałościach najwcześniejszego zamku biskupów chełmińskich - w Wąbrzeźnie. Poza wspomnianym sięgnięciem po wieżę jako symbol władzy feudalnej, wprowadzono tam bowiem na dziedziniec niewystępujące na zamkach krzyżackich reprezentacyjne ceglane i przesklepione schody, wiodące na ganek i główną kondygnację skrzydła południowego ${ }^{107}$ (il. 2:B).

Podsumowując stwierdzić więc należy, że dostojnicy kościelni świadomie sięgnęli po model kasztelu, który w Prusach miał już jasne konotacje z władzą centralną. Nie bez znaczenia była tu na pewno też przynależność większości kapituł i biskupów do zakonu. W miarę możliwości finansowych, początkowo zatrudnili mniej doświadczone warsztaty, naśladując tylko formę (Wąbrzeźno), by potem zaangażować budowniczych pracujących bez watpienia przy inwestycjach krzyżackich i obeznanych ze stosowaną przy nich techniką budowlaną. Biskupi i kapituły przejmowali model zamku konwentualnego w aktualnie obowiązujących formach (niezapóźnionych) i twórczo go dostosowywali do swoich potrzeb funkcjonalnych i semantycznych, przez co otrzymywały one indywidualny charakter, odróżniający je od schematyzmu i surowości zamków korporacji krzyżackiej. Nie były więc po prostu naśladownictwem, ale wyrazem możliwości twórczych i intelektualnych oraz aspiracji hierarchii kościelnej, z jednej strony akcentującej swoje związki z zakonem, z drugiej zaś niezależność swojej władzy feudalnej w dominiach.

107 WAsIK, „Układ przestrzenny zamku w 1. połowie XVII wieku”, s. 59. 


\section{Castellum-type Castles as Residences of Church Dignitaries in Prussia}

Several dozen years after the Teutonic Knights had started raising their first castles, brick defensive residences were also built by bishops and chapters. In the early $14^{\text {th }}$ century, Church dignitaries decided to apply the castellum-type Teutonic conventual house, adapting the model to their purposes. The oldest of the facilities, namely the Wąbrzeźno Castle, is characterized e.g. by poorer craftsmanship and untypical building techniques, this showing that the bishops employed less initiated specialists. Later castles (built e.g. in Lubawa and Kwidzyń in ca 1320-1350 and in Lidzbark Warmiński in ca 1350 1353) feature the typical qualities of the Teutonic castellum-type facilities: proportions designed ad quadratum, repeatable construction phasing consisting in launching the project from the perimeter curtain, followed by adding subsequent wings, and a wide range of earthworks. The functional layout of interiors displays differences, however some similarities can also be found. The first resulting to a great degree from the practical needs of the owners; this seen, e.g. in the bishop's suite replacing the collective dormitory. Episcopal and capitular castles do not manifest any outdated style features, as they were erected in compliance with the current models, yet as distinct from the Teutonic castles, they are more residential in character, and the choice of different emphases can be found with respect to the propaganda of the authority and architectural symbolism. An example of the latter can be seen in defensive belfries being supplanted mainly by towers of symbolism meant to promote the feudal power of Church dignitaries taking precedence over the defensive function. 


\section{Bibliografia:}

Andrzejewski, Aleksander, i Leszek Kazjer. "The Chelmno bishops' castle in Lubawa in the light of the latest research." W Castella Maris Baltici, t. 6, redakcja Albinas Kuncevičius, 17-22. Vilnius: Savastis, 2004.

Brzostowska, Izabela. "Die Haupttürme der Burgen in Heilsberg und Rössel - zwei gegensätzliche Werke in der Wehrarchitektur Ermlands." W Echte Wehrhaftigkeit oder martilische Wirkung. Zur praktischen Funktion und zum Symbolcharakter von Wehrelementen profaner sakraler Bauten im Deutschordensland Preußen und im Ostseeraum, redakcja Gerhard Eimer, Ernst Gierlich, 101-110. Köln: Wissenschaft und Politik, 2000.

Clasen, Karl Heinz. Die mittelalterliche Kunst im Gebiete des Deutschordensstaates Preussen, t. 1: Die Burgbauten. Königsberg: Gräfe und Unzer Verlag, 1927.

Dobry, Artur. "Dziewiętnastowieczne prace restauratorskie w zespole zamkowo-katedralnym w Kwidzynie." Komunikaty Mazursko-Warmińskie 1 (1994): 35-42.

Glauert, Mario. Das Domkapitel von Pomesanien (1284-1527). Toruń: Wydawnictwa Naukowe UMK, 2003.

Heise, Johannes. Der Kreis Löbau. Danzig: Kommissions-Verl. von Th. Bertling, 1895.

Heise, Johannes. Der Kreis Marienwerder östlich der Weichsel. Danzig: Kommissions-Verl. von Th. Bertling, 1898.

Herman, Radosław. "Nowe spojrzenie na przedzamcze w Lidzbarku Warmińskim. Wstępne wyniki badań archeologicznych." W Dni dziedzictwa Warmii. "Skarby Warmii”, 63-90. Lidzbark Warmiński: Starostwo Powiatowe, 2009.

Herrmann, Christofer. "Die pomesanische Kapitelsburg und der Dom in Marienwerder." W Burg und Kirche. Herrschaftsbau im Spannungsfeld zwischen Politik und Religion, redakcja Joachim Zeune, Hartmut Hofrichter, 231-242. Würzburg: Deutsche Burgenvereinigung, 2013.

Herrmann, Christofer. "Heilsberg im Kontext des ermländischen Burgenbaus." W Burgen kirchlicher Bauherren, red. Georg Grossman, Hans Häffner, 223-230. München-Berlin: Deutsche Kunstverlag, 2001.

Herrmann, Christofer. Mittelalterliche Architektur im Preussenland. Untersuchungen zur Frage der Kunstlandschaft und -Geographie. Olsztyn: Artes; Petersberg: Michael Imhof Verlag, 2007.

Herrmann, Christofer. "Mittelalterliche Bischofs- und Kapitelsburgen im Preußenland." Burgenforschung aus Sachsen. Beiträge zur Burgenforschung im Freistaat Sachsen und angrenzender Gebiete 15/16 (2003): 153-177.

Jarzebowski, Marc. Die Residenzen der Preussischen Bischöfe bis 1525. Toruń: Wydawnictwa Naukowe UMK, 2007.

Kaczyński, Bartłomiej, Adam Mackiewicz, i Iwona Zduńska. "Badania archeologiczne zamku biskupów chełmińskich w Lubawie w latach 2015-2016." W Materiały do archeologii Warmii 
i Mazur, t. 2, redakcja Sławomir Wadyl, Maciej Karczewski, Mirosława Hoffmann, 343-358. Warszawa-Białystok-Olsztyn: Instytut Archeologii Uniwersytetu Warszawskiego, Wydział Historyczno-Socjologiczny Uniwersytetu w Białymstoku, Instytut Historii i Stosunków Międzynarodowych Uniwersytetu Warmińsko-Mazurskiego w Olsztynie, 2018.

Koperkiewicz, Arkadiusz. "Badania archeologiczne na południowym tarasie zamku biskupów w Lidzbarku Warmińskim.” Gdańskie Studia Archeologiczne 5 (2015): 113-174.

Krantz, Liliana, i Jerzy Domasłowski. Katedra i zamek w Kwidzynie. Warszawa-Poznań-Toruń: PWN, 1982.

Krantz-Domasłowska, Liliana. "Der Dom und die Burg in Marienwerder (Kwidzyn)." W Burgen kirchlicher Bauherren, redakcja Georg Grossman, Hans Häffner, 215-222. München-Berlin: Deutsche Kunstverlag, 2001.

Krantz-Domasłowska, Liliana. "Katedra i zamek w Kwidzynie jako założenie obronne.” Folia Fromborcensia 1 (1992): 24-28.

Majewski, Maciej, Bogusz Wasik, i Marcin Wiewióra. "Studia nad warsztatem budowlanym zamku biskupów chełmińskich w Wąbrzeźnie.” Wiadomości Konserwatorskie 38 (2014): 54-65.

Pilecka, Elżbieta. "Residenz der ermländischen Bischöfe in Heilsberg (Lidzbark Warmiński) in der zweiten Hälfte des 14. Jahrhunderts." W Prag und die grossen Kulturzentren Europas in der Zeit der Luxemburger (1310-1437), redakcja Markéta Jarošová, Jiř́i Kuthan, Stefan Scholz, 257277. Praha: Togga 2008.

Raczkowski, Juliusz. "Medieval murals recently uncovered in the chamber above the gate of the castle of the chapter of the diocese of Pomesania in Kwidzyn. Preliminary analysis: iconography, style, dating and functional role of the chamber." Ordines Militares Colloquia Torunensia Historica 22 (2017): 287-304.

Radzimiński, Andrzej. "Geneza oraz ukształtowanie się organizacji kościelnej (1206-1409)." W Państwo zakonu krzyżackiego w Prusach. Władza i społeczeństwo, redakcja Marian Biskup, Roman Czaja, 143-176. Warszawa: PWN, 2009.

Schmid, Bernhard. Die Domburg Marienwerder. Elbing: Preussenverlag, 1938.

Trupinda, Janusz. "Zamek w Kwidzynie w czasach bł. Doroty z Mątowów na podstawie średniowiecznych źródeł historycznych.” W Studia z dziejów diecezji Pomezańskiej w 775. rocznice jej utworzenia. Materiały z V. Sympozjum Dorotańskiego w Kwidzynie, redakcja Justyna Liguz, 1931. Pelplin: Wydawnictwo "Bernardinum”, 2020.

Wasik, Bogusz. Budownictwo zamkowe na ziemi chetmińskiej (od XIV do XV wieku). Toruń: Wydawnictwo Naukowe UMK, 2016.

Wasik, Bogusz. "Metoda projektowania zamków konwentualnych na ziemi chełmińskiej. Przyczynek do badań nad zastosowaniem kwadratury w krzyżackim budownictwie zamkowym." Kwartalnik Architektury i Urbanistyki 58, nr 4 (2012): 79-91.

Wasik, Bogusz. "Techniki budowy zamków w typie kasztelu w państwie krzyżackim w Prusach.” Ochrona Zabytków 71, nr 2 (2018): 33-60. 
Wółkowski, Wojciech. Zamek biskupów warmińskich w Lidzbarku Warmińskim-dzieje budowlane i problemy konserwatorskie. Olsztyn: Muzeum Warmii i Mazur, 2016.

Zamek biskupów chetmińskich w Wąbrzeźnie w świetle badań archeologiczno-architektonicznych. Studia i materiaty, redakcja Marcin Wiewióra. Toruń: Wydawnictwo Naukowe UMK, 2014.

Zamek w Lubawie. Dawniej i dziś, redakcja Leszek Kajzer. Lubawa: Urząd Miasta, 2001. 